\title{
Selective Tight Binding Inhibitors of Trypanosomal Glyceraldehyde-3-phosphate Dehydrogenase via Structure-Based Drug Design
}

\author{
Alex M. Aronov, ${ }^{\dagger}$ Christophe L. M. J . Verlinde, ${ }^{\S}$ Wim G. J . Hol, , ${ }^{\S, \neq}$ and Michael H. Gelb*,† \\ Departments of Chemistry, Biochemistry, and Biological Structure, University of Washington, \\ Seattle, Washington 98195, and Howard Hughes Medical Institute, Seattle,Washington 98195
}

Received April 30, 1998

\begin{abstract}
Glyceraldehyde-3-phosphate dehydrogenase (GAPDH) from the sleeping sickness parasite Trypanosoma brucei is a rational target for anti-trypanosomatid drug design because glycolysis provides virtually all of the energy for the bloodstream form of this parasite. Glycolysis is also an important source of energy for other pathogenic parasites including Trypanosoma cruzi and Leishmania mexicana. The current study is a continuation of our efforts to use the X-ray structures of $\mathrm{T}$. brucei and $\mathrm{L}$. mexicana GAPDHs containing bound $\mathrm{NAD}^{+}$to design adenosine analogues that bind tightly to the enzyme pocket that accommodates the adenosyl moiety of $\mathrm{NAD}^{+}$. The goal was to improve the affinity, selectivity, and solubility of previously reported 2'-deoxy-2'-(3-methoxybenzamido)adenosine (1). It was found that introduction of hydroxyl functions on the benzamido ring increases solubility without significantly affecting enzyme inhibition. Modifications at the previously unexploited $\mathrm{N}^{6}$-position of the purine not only lead to a substantial increase in inhibitor potency but are also compatible with the 2'-benzamido moiety of the sugar. For $\mathrm{N}^{6}$-substituted adenosines, two successive rounds of modeling and screening provided a 330-fold gain in affinity versus that of adenosine. The combination of $\mathrm{N}^{6}$ - and $2^{\prime}$-substitutions produced significantly improved inhibitors. $\mathrm{N}^{6}{ }_{-}$-Benzyl (9a) and $\mathrm{N}^{6}{ }_{-}$ 2-methylbenzyl (9b) derivatives of $\mathbf{1}$ display $I C_{50}$ values against $L$. mexicana GAPDH of 16 and $4 \mu \mathrm{M}$, respectively (3100- and 12500-fold more potent than adenosine). The adenosine analogues did not inhibit human GAPDH. These studies underscore the useful ness of structure based drug design for generating potent and species-selective enzyme inhibitors of medicinal importance starting from a weakly binding lead compound.
\end{abstract}

\section{Introduction}

Sleeping sickness, caused by the protozoon Trypanosoma brucei, is considered by the World Health Organization to be one of the main tropical parasitic diseases, ${ }^{1}$ in which parasites invade and then freely live in the bloodstream of the mammalian host.2,3 The disease is fatal if left untreated. 3,4 Existing chemother$a^{3-12}$ has serious drawbacks, including severe side effects, low efficacy, increasing resistance, and no effect on the most virulent form of sleeping sickness caused by $T$. brucei rhodesiense. Other diseases caused by Trypanosomatidae include leishmaniasis (Leishmania genus) and Chagas disease (Trypanosoma cruzi ). 2,4

The work presented here focuses on glycolysis in trypanosomes as a target for structure-based drug design. It has been shown that upon going from insect to bloodstream form the parasites become fully dependent on glycolysis for energy production.2,13,14 Inhibiting glycolysis in parasites would be expected to slow their proliferation, as has been shown by Clarkson and Brohn for the combination of salicylhydroxamic acid and glycerol. ${ }^{15}$ Since the kinetic parameters for all of the enzymes in the glycolytic pathway in T. brucei are known, ${ }^{16}$ it has been possible to simulate parasite glycolytic flux in computro. ${ }^{17,18}$ Based on the compu-

\footnotetext{
* To whom correspondence should be addressed.

† Departments of Chemistry and Biochemistry.

$\S$ Department of Biological Structure.

‡ Howard Hughes Medical Institute.
}

tational result that the presence of a competitive inhibitor of hexokinase at a concentration in the range of $0-K_{\text {I }}$ $\left(K_{1}\right.$ is the dissociation equilibrium constant for the $\mathrm{E} \cdot \mathrm{I}$ complex) has little effect on glycolytic flux, it has been argued that competitive inhibitors of glycolytic enzymes will not be useful for blocking energy production. ${ }^{18}$ However, there is no basis for this general statement, as additional simulation studies have shown that glycolytic flux is reduced to 0 in the presence of competitive inhibitors of glyceral dehyde-3-phosphate dehydrogenase (GAPDH) and phosphoglycerate kinase present at [I]/K $=10-100 .{ }^{19}$

A comparison of the crystal structures of parasite and mammalian glycolytic enzymes forms the basis for rational design of selective inhibitors. Analysis revealed distinct structural differences for GAPDH. ${ }^{20-23}$ Glycosomal GAPDH isolated from trypanosomes has been studied previously, ${ }^{16}$ and irreversible nonselective inhibitors have been developed. ${ }^{24}$

The adenosyl moiety of $\mathrm{NAD}^{+}$does not directly contribute to catalysis and is sufficiently removed from the essential active site cysteine residue, and the amino acid sequence and the position of the protein backbone around it are not completely conserved between human and trypanosomal GAPDH (Figure 1). Significant differences are found next to the conserved T. bruce Asp 37 (Asp 34 in human GAPDH) which anchors the adenosine moiety by forming hydrogen bonds to its 2'and 3'-hydroxyls. In trypanosomal enzymes the backbone is further away from the nucleoside, resulting in 

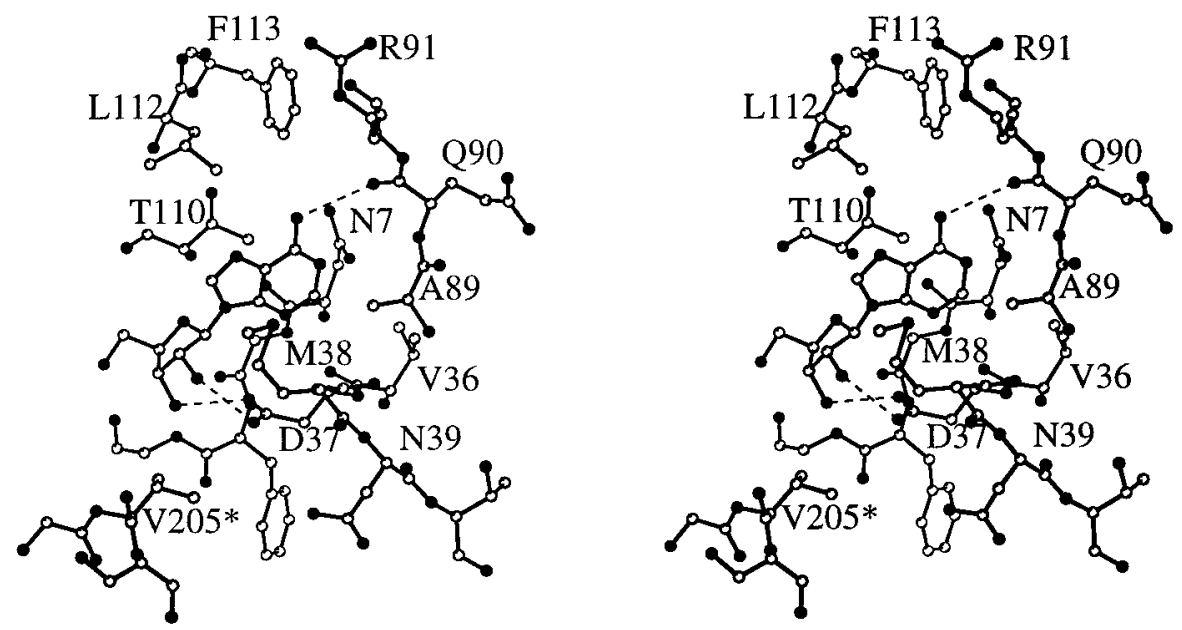

Figure 1. Stereofigure showing the adenosyl moiety of $\mathrm{NAD}^{+}$bound to glycosomal T. bruce GAPDH. Hydrogen bonds are shown as dashed lines.

\section{Chart 1}<smiles>COc1cccc(C(=O)NC2C(O)C(CO)OC2n2cnc3c(N)ncnc32)c1</smiles>

1

a cleft near the 2 '-position of the sugar. Flanked by Asn 39 in the T. bruce enzyme (Ser 40 in the L. mexicana enzyme), this cleft does not exist in the human enzyme because it is essentially filled by Ile 37.23 This fact was exploited by Verlinde et al.20,21 who designed, synthesized, and tested a number of 2 '-substituted adenosines with adenosine as a lead $\left(\mathrm{IC}_{50}\right.$ value around $\left.50 \mathrm{mM}\right)$. The best result was achieved with 2'-deoxy-2'-(3-methoxybenzamido)adenosine (1) (Chart 1 ) (I $C_{50}$ values of 0.3 $\mathrm{mM}$ for $\mathrm{L}$. mexicana GAPDH, $2.2 \mathrm{mM}$ for $\mathrm{T}$. brucei GAPDH, and >10 mM for human GAPDH). While using a 2'-amido functional group to preserve the hydrogen bond to the Asp anchor, the design exploited the differences in cleft size and achieved remarkable specificity compared to adenosine, possibly involving a hydrogen bond from the amido function of Asn 39 in T. bruce GAPDH to the methoxy oxygen of $\mathbf{1}$.

Despite the success in achieving substantial selectivity, the affinity of the best trypanosomal GAPDH inhibitor is still far too low for it to become a valuable drug in treating trypanosomal infections. Attempts to simplify the structure by using cyclopentyl and openchain adenine derivatives were only marginally successful. ${ }^{22}$ The 2 '-substituent proved to be incompatible with substituents on the adenine ring such as $\mathrm{C}^{2}$ methyl ${ }^{22}$ or $\mathrm{C}^{8}$-thienyl, ${ }^{20}$ which as monosubstitutions led to a 10- and 180-fold increase in GAPDH affinity, respectively, over adenosine.

In the present study mono- and dimodifications of adenosine have been introduced at positions $2^{\prime}$ and $\mathrm{N}^{6}$ based on modeling studies. Their effect on GAPDH inhibition has been measured, and optimization was carried out. I nhibitors with significantly higher activity have been obtained. Compatibility of $2^{\prime}, N^{6}$-disubstitution has been established and should allow for further improvement of the inhibitors currently under study.

\section{Molecular Modeling}

Initially, we decided to test the disposition of atoms in the modeled structure of T. bruce GAPDH.1 by adding substituents on the benzamido group at positions that were predicted from the trypanosomal GAPDH $X$-ray structures not to sterically interfere with binding. Because of the ease of synthesis and possible improvement in solubility, introduction of hydroxyl groups was considered. The proposed binding mode of $\mathbf{1}^{20}$ involves the occupation by a 3-methoxybenzamido group of a mainly hydrophobic and narrow enzyme cleft that starts near the ribosyl 2'-position and widens near Asn 39 (Figure 1 ). The main recognition features of this substituent are (i) a hydrogen bond between the ami de nitrogen and the carboxylate of Asp 37, (ii) sandwiching of the aromatic ring by Met 38 and Val 205* (the latter residue is provided by a neighboring subunit of the GAPDH tetramer), and (iii) a hydrogen bond between the methoxy group and ND2 of Asn 39 (predicted hydrogen bond length $3.3 \AA$ ). From inspection of this model it appeared that positions 4 and 5 of the 3-methoxybenzamido were prime candidates for substitution as they were pointing mainly into solvent. Position 2 was also considered, with the possibility of forming an intramolecular hydrogen bond to the 2'-ami de nitrogen; such a conformation can be observed in 15 out of 51 2-hydroxybenzamido groups in the Cambridge Crystallographic database with a hydrogen bond length of 2.63 \pm 0.04 A. However, intermolecular contacts did not look favorable sincea hydroxyl at position 2 would bump into the OD2 of Asp 37 (predicted distance 2.35 $\AA$ ). In conclusion, modeling suggested that the introduction of a 4-hydroxyl and a 5-hydroxyl would leave the affinity of $\mathbf{1}$ unchanged, whereas a 2-hydroxyl would disrupt its binding mode and decrease the GAPDH binding affinity.

The next step was to increase the affinity of our best parasite-selective lead compound $\mathbf{1}$ by adding substituents to the adenine ring. Because the 8- and 2-substituents discovered during our previous design studies $^{20}$ are incompatible with the 2 '-(3-methoxybenzamido) 

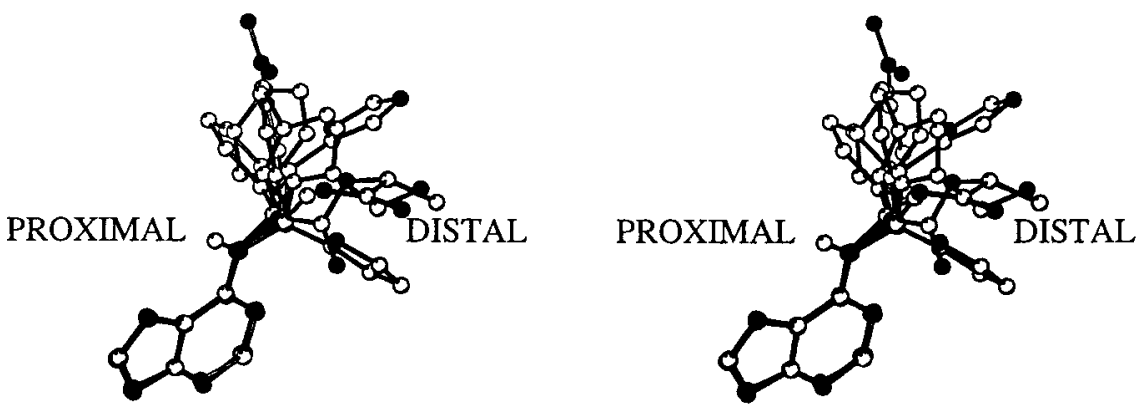

Figure 2. Superposition of the 15 substituted $\mathrm{N}^{6}$-methyleneadenines present in the Cambridge Crystallographic Database (stereoview). All $\mathrm{N}^{6}$-substituents are oriented distal with respect to the imidazole of the adenine ring. In contrast, our proposed binding mode in GAPDH has the substituent in the proximal orientation.

moiety due to steric clashes between the introduced substituents, ${ }^{22}$ we tried to explore the possibility of introducing substituents at the $\mathrm{N}^{6}$ position. In proximity to that atom, two hydrophobic clefts exist (Figure 1). One is formed by the side chains of Leu 112 and Phe 113 and the backbone and first two side-chain atoms of Arg 91 (narrow cleft). The second site (wide cleft) points in the opposite direction and is formed by the side chains of Met 38 and Ala 89 and the backbone of Ala 89. We assayed the L. mexicana GAPDH inhibition potency of 11 commercially available $\mathrm{N}^{6}$-substituted adenosine derivatives that might project a hydrophobic group into the aforementioned clefts. One of the best inhibitors was $\mathrm{N}^{6}$-benzyladenosine with an affinity for L. mexicana GAPDH which was nearly 10-fold higher than that of adenosine. Because a semirandom synthesis of nine more $\mathrm{N}^{6}$-adenosine derivatives $(\mathbf{7 a}-\mathbf{i})$ did not significantly improve on the lead (see Results and Discussion), we decided to pursue derivatization by structure-based inhibitor design methods.

Design was carried out as follows. First, we decided on a synthesis concept of reacting commercially available primary amines with 6-chloropurine riboside. From the Available Chemicals Directory (ACD 95.2), 1124 such compounds were retrieved. After filtering out large compounds $\left(\mathrm{M}_{\mathrm{r}}>250\right)$ and compounds with additional reactive functionalities, 88 compounds remained. These were clustered based on their frameworks: 19 mono-, 13 di-, and 3 trisubstituted benzylamines, $22 \alpha$-substituted benzylamines, 8 bicyclic compounds, and 23 structures with no apparent similarity to each other. All of the substituents were graphically attached at the $\mathrm{N}^{6}$-position of the adenosine framework and docked individually into the protein environment. Adenosyl moiety coordinates from X-ray data for $\mathrm{NAD}^{+}$were used as a starting point. Each time both the narrow and the wide cl eft binding modes were considered for the $\mathrm{N}^{6}$-substituent. On the basis of steric fit, amount of hydrophobic surface buried, and ease of synthesis, six compounds were selected for synthesis (7j-0).

It should be noted that in all cases we opted for $\mathrm{a}^{6} \mathrm{C}_{-}$ $\mathrm{N}^{6}$ dihedral angle such that the $\mathrm{N}^{6}$-substituent was oriented proximal to the imidazole fragment of adenosine in order to avoid severe clashes with the protein backbone of Arg 91. This is in contrast with the distal orientation seen in 15 out of 15 structures in the Cambridge Crystallographic Database, which is usually attributed to avoidance of a steric interference between $\mathrm{N}^{7}$ of adenosine and the $\alpha$-methyl(ene) at position $\mathrm{N}^{625}$
Scheme $1^{a}$

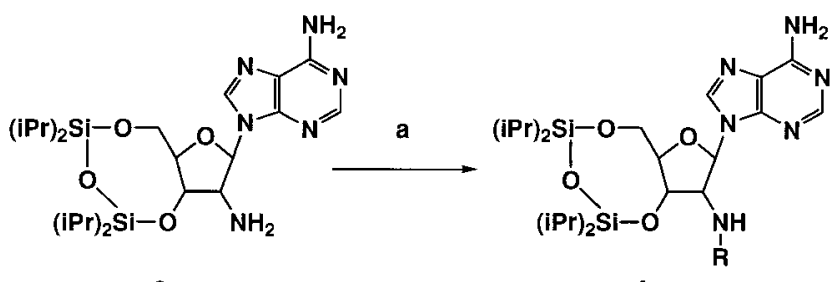

3<smiles>Nc1ncnc2c1ncn2C1OC(CO)C(O)C1NP</smiles>

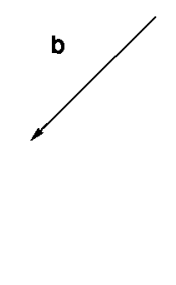

1,5

1, 4a: $\mathrm{R}=3$-methoxybenzoyl

4, 5b: $R=3$-methoxy-4-hydroxybenzoyl

4, 5c: $\mathrm{R}=2$-hydroxy-3-methoxybenzoyl

4, 5d: $\mathrm{R}=3$-hydroxybenzoyl

$4,5 \mathrm{e}: \mathrm{R}=3,4,5$-trihydroxybenzoyl

4, 5f: $\mathrm{R}=3,5$-dihydroxybenzoyl

a $\mathrm{RCOCl}, 10: 1 \mathrm{CH}_{2} \mathrm{Cl} /$ pyridine; (b) $\mathrm{NH}_{4} \mathrm{~F}$, methanol.

(Figure 2). However, steric interference is not so severe because in none of the doubly $\mathrm{N}^{6}$-substituted adenosine derivatives in the CSD do the $\alpha$-methyl(ene) groups at the $\mathrm{N}^{6}$-position rotate out of the plane of the purine ring. We carried out a semiempirical quantum chemical calculation with the AM 1 Hamiltonian on $\mathrm{N}^{6}$-methyladenine. It indicated that the distal conformation is preferred by only $2 \mathrm{kcal} / \mathrm{mol}$ over the proximal one. Hence, we concluded that our proposed binding conformation about $\mathrm{C}^{6}-\mathrm{N}^{6}$ for the adenosine analogue bound to GAPDH is plausible.

\section{Chemistry}

Compounds $\mathbf{5 b} \mathbf{b}-\mathbf{f}$ were prepared by direct acylation of the Markiewicz-protected 2'-amino nucleoside 3 followed by fluoride-promoted desilylation in $\mathrm{MeOH}^{21}$ (Scheme 1). Precursor 3 was made from adenine 9- $\beta$ D-arabinofuranosi de (Ara-A) according to the previously published procedures. ${ }^{21,26}$ Hydroxyl functionalities on the benzoyl fragment were protected via $\mathrm{AlCl}_{3}$-catalyzed acetylation ${ }^{27}$ prior to activation of the substituted benzoic acids with $\mathrm{PCl}_{5}$; the acetates were subsequently removed in $\mathrm{NH}_{3} / \mathrm{MeOH}$.

Monosubstituted $\mathrm{N}^{6}$-alkyladenosines were prepared in a one-step conversion from 6-chloropurine riboside 


\section{Scheme 2}
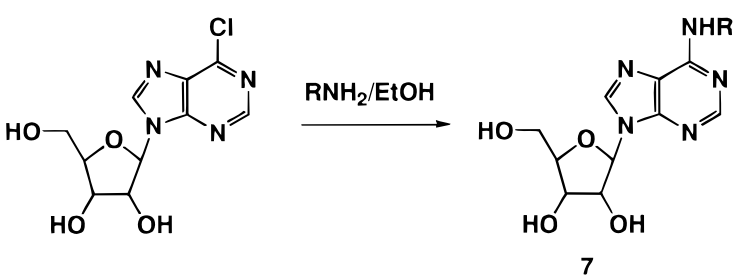

7a: $\mathrm{R}=$ isopropyl

$7 \mathrm{~b}: \mathrm{R}=\mathrm{t}$-butyl

7c: $\mathrm{R}=\mathrm{n}$-amyl

$7 \mathrm{~d}: \mathrm{R}=2$-amyl

7e: $\mathrm{R}=2$-methylbutyl

7f: $\mathrm{R}=$ isoamyl

$7 \mathrm{~g}: \mathrm{R}=3$-methyl-2-butenyl

$7 \mathrm{~h}: \mathrm{R}=$ cyclopentyl

7i: $\mathrm{R}=$ cycloheptyl

7j: $\mathrm{R}=2$-methylbenzyl

$7 \mathrm{k}: \mathrm{R}=3$-methylbenzyl

7l: $\mathrm{R}=1$,2,3,4-tetrahydro-1-naphthyl

$7 \mathrm{~m}: \mathrm{R}=1$-naphthalenemethyl

$7 \mathrm{n}: \mathrm{R}=2$-[2-(hydroxymethyl)

phenylthio]-benzyl

by nucleophilic substitution with an amine 28,29 (Scheme 2). The only exception was $\mathrm{N}^{6}$-(3-methyl-2-butenyl)adenosine. In this case, prenyl bromide was used to al kylate adenosine, and the $\mathrm{N}^{6}$-al kylated intermediate was rearranged under Dimroth conditions to yiel $\mathbf{~} \mathbf{7 g} .{ }^{30}$ To obtain the $\mathrm{N}^{6}$-isobutyryl derivative $\mathbf{6}$ a, the protected analogue $\mathbf{4 a}$ was first acylated with isobutyryl chloride and then subjected to $\mathrm{NH}_{4} \mathrm{~F} / \mathrm{MeOH}$ deprotection.

The quickest pathway to $2^{\prime}, \mathrm{N}^{6}$-disubstituted series 9a-e (see Scheme 3) involved subjecting $4 \mathbf{a}$ to alkylation by substituted benzyl bromides with subsequent Dimroth rearrangement, the sequence explored by Robins and co-workers. ${ }^{30}$ 2-Methoxy-, 2,5-dimethyl-, and 2,3-dimethylbenzyl bromides were prepared from the corresponding al cohols using $\mathrm{PBr}_{3}, 31$ 2,3-dimethyl benzyl alcohol was made via $\mathrm{LiAlH}_{4}$ reduction of the respective benzoic acid. ${ }^{32}$

\section{Results and Discussion}

Parasite GAPDH and Drug Design. Despite the fact that model ing studies were carried out on GAPDH from $T$. bruce, , most of the structure-activity relationship (SAR) work was done with the L. mexicana GAPDH, which overexpresses in Escherichia coli significantly better than the T. bruce enzyme. The amino acid sequences of the two parasite GAPDHs are $81 \%$ identical, and the structures of the binding pockets for the adenosyl moiety of $\mathrm{NAD}^{+}$are virtually identical except at one position (Asn 39 for T. bruce GAPDH and Ser 40 for L. mexicana GAPDH). The rms deviation in back bone atoms for the residues in this pocket is $0.2 \AA$; the rms deviation for the side-chain atoms is $0.5 \AA .{ }^{33}$ The conformations of $\mathrm{NAD}^{+}$in the two enzymes are also essentially superimposable. In previous studies, it was found that 2'-(3-methoxybenzamido)adenosine analogues typically bind $\sim 8$-fold tighter to L. mexicana GAPDH versus T. bruce GAPDH. 20 This may be due in part to the Asn 39/Ser 40 difference. In the present study, our better inhibitors of $L$. mexicana GAPDH were also tested on T. bruce and T. cruzi GAPDHs. The residues comprising the adenosyl binding pockets of the latter two enzymes are identical.

Structure-Activity Relationships. Introduction of hydroxyl groups on the benzamide ring of $\mathbf{1}$ moderated affinity of the inhibitors for L. mexicana GAPDH by less than 4-fold (Table 1). Hydroxyls were tolerated at positions $2-5$. The addition of the 2- and 4-hydroxyls led to a minimal improvement in binding: 1.3- and 1.6- fold, respectively. I dentical potency of compounds $\mathbf{1}$ and 5d, with a 3-OMe and a 3-OH substitution, respectively, most likely argues against the earlier suggestion that 1 benefits from the interaction of its methoxy substituent with Val 207* of the neighboring subunit. ${ }^{22}$ However, both groups could possibly form a hydrogen bond to Asn 39 of T. bruce GAPDH. The most soluble compound of the series, $\mathbf{5 e}$, with three hydroxyls on the benzamide, is 3-fold more potent than $\mathbf{1}$. Unfortunately, ortho-oxidation is common for gallic acid derivatives, ${ }^{34}$ and the resulting o-quinone metabolites are highly reactive toward nucleophiles present in the cell. ${ }^{34,35}$ To take advantage of both affinity and solubility of $\mathbf{5 e}$, compound $\mathbf{5 f}$ was synthesized. Its affinity was lower, but the stability was improved. In summary, the effect that different modifications at position 2' had on inhibitor potency is consistent with our model of the 2'benzamido moiety occupying the hydrophobic cleft in trypanosomal GAPDHs.

The $\mathrm{N}^{6}$-position was initially investigated via the testing of commercially available monosubstituted nucleosides. GAPDH binding was sel ective for secondary amines over amides (Table 2). Compound 6a, incorporating the isobutyryl moiety, exhibited both decreased affinity and drastically lower solubility as compared to $\mathbf{1}$. The screening affor ded hits $\mathbf{6 b}-\mathbf{d}$, which showed $12-$ 16-fold improvement in binding compared to adenosine (Table 2). They all shared a secondary amine substitution at the $\mathrm{N}^{6}$-position.

Subsequently we synthesized a series of $\mathrm{N}^{6}$-substituted adenosine derivatives to explore the use of small aliphatic chains in a semirandom manner. This re vealed a clear trend that substituents with more hydrophobic bulk increased binding to GAPDH (see Table 3). I sopropyl (7a) and tert-butyl (7b) chains were too short and thus unable to reach either of the two hydrophobic clefts. Longer chains, both straight and branched close to the nitrogen, had no effect on affinity. As branching moved further away along the chain, binding improved, and the $\mathrm{N}^{6}$-i soamyl derivative $7 f$ was the most active noncyclic amine adduct in the series with an $\mathrm{IC}_{50}$ of $3.7 \mathrm{mM}$ (10-fold improvement over adenosine). This correlates with the activity of dihydrozeatin riboside $(\mathbf{6 d})$, as the structures for these two compounds are identical except for the terminal $\delta$-alcohol present in $\mathbf{6 d}$. Straightening the isoamyl chain by introducing a double bond $(\mathbf{7 g}$ ) abbrogated nearly half of the $\mathrm{N}^{6}$-isoamyl binding contribution. The relative success of adenosines containing $\mathrm{N}^{6}$-cyclic amines $(\mathbf{7 h}, \mathbf{i})$ indicates that flexible cyclic substituents with considerable hydrophobic surface complement the enzyme surface as well as flat aromatic systems.

At this point the $\mathrm{N}^{6}$-substituent was optimized by using a benzyl substituent as the basis for the second round of drug design. The benzyl moiety provided both the rigid framework and the wealth of structural analogues for further optimization of the $\mathrm{N}^{6}$-substituent. In an effort to better fill the hydrophobic clefts, compounds $\mathbf{7 j}-\mathbf{o}$ were synthesized from the amines chosen from the Available Chemicals Directory (see Mol ecular Modeling) and tested against L. mexicana GAPDH. The results are summarized in Table 3. As predicted from modeling, a methyl group introduced at either the orthoor meta-position on the benzyl ring $(\mathbf{7 j}, \mathbf{k})$ improved 


\section{Scheme $3^{a}$}

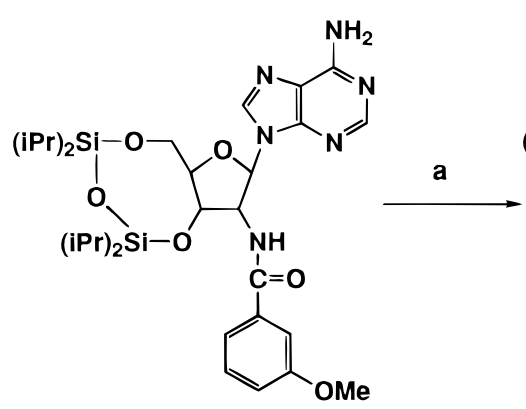

$4 a$

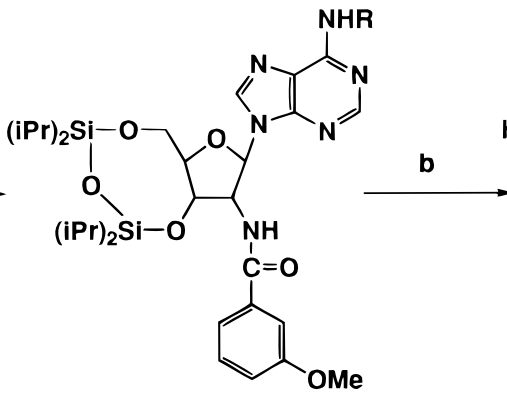

8<smiles>CCNC1=NC=NC2C1NCN2C1OC(CO)C(O)C1NC(=O)c1cccc(OC)c1</smiles>

9

$$
\begin{aligned}
& \text { 9a: } R=\text { benzyl } \\
& \text { 9b: } R=2 \text {-methylbenzyl } \\
& \text { 9c: } R=2 \text {-methoxybenzyl } \\
& \text { 9d: } R=2,5 \text {-dimethylbenzyl } \\
& \text { 9f: } R=2,3 \text {-dimethylbenzyl }
\end{aligned}
$$

a (a) $\mathrm{RBr}, \mathrm{DMF}, 45^{\circ} \mathrm{C}$, then iPr- $\mathrm{NH}_{2} /$ methanol (1:3), reflux; (b) $\mathrm{NH}_{4} \mathrm{~F}$, methanol.

Table 1. Inhibition of L. mexicana GAPDH by 2'-Deoxy-2'-benzamidoadenosine Analogues

\begin{tabular}{clllll}
\hline & \multicolumn{4}{c}{ 2'-benzamido substituent } & \\
\cline { 2 - 4 } compd & $\mathrm{R}_{2}$ & $\mathrm{R}_{3}$ & $\mathrm{R}_{4}$ & $\mathrm{R}_{5}$ & IC $_{50}(\mu \mathrm{M})$ \\
\hline $\mathbf{1}$ & $\mathrm{H}$ & $\mathrm{OMe}$ & $\mathrm{H}$ & $\mathrm{H}$ & 800 \\
$\mathbf{5 b}$ & $\mathrm{H}$ & $\mathrm{OMe}$ & $\mathrm{OH}$ & $\mathrm{H}$ & 500 \\
$\mathbf{5 c}$ & $\mathrm{OH}$ & $\mathrm{OMe}$ & $\mathrm{H}$ & $\mathrm{H}$ & 600 \\
$\mathbf{5 d}$ & $\mathrm{H}$ & $\mathrm{OH}$ & $\mathrm{H}$ & $\mathrm{H}$ & 850 \\
$\mathbf{5 e}$ & $\mathrm{H}$ & $\mathrm{OH}$ & $\mathrm{OH}$ & $\mathrm{OH}$ & 250 \\
$\mathbf{5 f}$ & $\mathrm{H}$ & $\mathrm{OH}$ & $\mathrm{H}$ & $\mathrm{OH}$ & 650 \\
\hline
\end{tabular}

Table 2. Initial Screening of $\mathrm{N}^{6}$-Substituted Adenosine Analogues as Inhibitors of L. mexicana GAPDH ${ }^{a}$

\begin{tabular}{lc}
\hline \multicolumn{1}{c}{ compd } & $\mathrm{IC}_{50}(\mu \mathrm{M})$ \\
\hline adenosine & $50,000^{22}$ \\
$\mathrm{~N}^{6}$-isobutyryl-2'-deoxy-2'-(3-methoxybenzamido)- & 1,200 \\
adenosine (6a) & \\
$\mathrm{N}^{6}$-benzyladenosine (6b) & 4,200 \\
$\mathrm{~N}^{6}$-(4-aminobenzyl)adenosine (6c) & 3,100 \\
$\mathrm{~N}^{6}$-(4-hydroxy-3-methylbutyl)adenosine & 3,400 \\
(dihydrozeatin riboside) (6d) &
\end{tabular}

${ }^{a} K_{I}$ values can be calculated from $I C_{50}$ values using the standard formula for competitive inhibition, $\left[\mathrm{NAD}^{+}\right]=0.19 \mathrm{mM}$, and $\mathrm{K}_{\mathrm{M}}\left(\mathrm{NAD}^{+}\right)=0.4 \mathrm{mM}$ for $\mathrm{L}$. mexicana GAPDH, 0.47 for $\mathrm{T}$. cruzi GAPDH, and 0.54 for T. brucei GAPDH. ${ }^{36}$

inhibition. This can be explained by a further insertion of the substituent into the narrow cleft; molecular mechanics analysis suggests a slight rotation of the side chain of Leu 112 away from Phe 113 as a way to widen the narrow cleft and make favorable interactions possible. Alternatively, partial interaction of benzyl with the narrow cleft and of the methyl with the wide cleft is also possible. Tetraline derivative 7l, modeled as either S or R at the new asymmetric center, seemed to cap the narrow hydrophobic cleft rather than enter it. Compound $\mathbf{7 m}$ was the most potent inhibitor in the series (330-fold better than adenosine), most likely by making good van der Waals contacts with the narrow or the wide cleft, but the presence of the naphthalene moiety severely compromised its solubility, which is only $10 \%$ higher than its $I_{50}$ in $5 \%$ DMSO/buffer. The aromatic thi oether substituent in $\mathbf{7 n}$ seemed, according to our model, to partially expose the second benzene ring to solvent, while 7o with a diphenylmethyl substituent may take advantage of both hydrophobic clefts.
The combination of $\mathrm{N}^{6}$-benzyl and 2'-(3-methoxybenzamide) groups on the adenosine scaffold (9a) led to a significant improvement in affinity for GAPDH. The $\mathrm{IC}_{50}$ of $16 \mu \mathrm{M}$ is 50 -fold lower than that of $\mathbf{1}$ and 3100fold lower than that of adenosine, the original lead compound. The modeled binding modes for $\mathbf{9 a}$ are shown in Figure 3. The 2'-substituent fills the selectivity cleft, while the benzyl moiety can occupy either of the two hydrophobic clefts proximal to $\mathrm{N}^{6}$ of adenosine. There is a synergistic effect with respect to the individual contributions of the substituents (Table 4). Compound 9a did not detectably inhibit human GAPDH when tested up to its solubility limit of $\sim 0.5 \mathrm{mM}$. It was shown to be a competitive inhibitor of trypanosomal GAPDH with respect to NAD ${ }^{+}$(Figure 4). Based on the results with $\mathbf{7 j}$, a 2-methyl group was introduced onto $9 \mathbf{a}$ to give $\mathbf{9 b}$. This compound is 4 -fold more active than 9a, while retaining its high selectivity for the parasite enzyme; compound $\mathbf{9 b}$ did not inhibit human GAPDH up to $0.27 \mathrm{mM}$. Despite the fact that human GAPDH also possesses the $\mathrm{N}^{6}$ pocket, the selectivity for $\mathbf{9 a}, \mathbf{b}$ is maintained. This selectivity is due to clash of the 2'benzamido substituent with Ile 37 in the human enzyme, and this will occur when the disubstituted adenosyl moiety sits in the active site of human GAP$\mathrm{DH}$. Other analogues did not show improved potency compared to $\mathbf{9 b}$. The 2-methoxybenzyl derivative $\mathbf{9 c}$ likely suffered from the putative desolvation of the oxygen upon binding into either of the hydrophobic enzyme clefts. Only an orientation into the narrow cleft appeared possible for $\mathbf{9 d}$; in the alternative orientation, the methyl in position 5 appeared to bump into the protein backbone of GIn 90. Addition of the 2,3dimethylbenzyl substitution (9e) did not improve binding compared to $\mathbf{9 b}$, despite the fact that the methyls increase the lipophilicity of the $\mathrm{N}^{6}$-substituent.

\section{Conclusions}

The X-ray structures of L. mexicana, T. brucei, and human GAPDH $\cdot \mathrm{NAD}^{+}$complexes have been used to identify clefts near the adenosyl moiety of $\mathrm{NAD}^{+}$that provide opportunity for structure-based inhibitor design. The most potent compound $\mathbf{9 b}$ represents for $\mathrm{L}$. mexicana GAPDH a 200-fold improvement over $\mathbf{1}$ and an 
Table 3. Inhibition of L. mexicana GAPDH by $\mathrm{N}^{6}$-Substituted Adenosine Analogues

\begin{tabular}{|c|c|c|}
\hline compd & $N^{6}-R$ & $\mathrm{IC}_{50}(\mu \mathrm{M})$ \\
\hline $7 a$ & & $n^{a}$ \\
\hline $7 \mathbf{b}$ & & $\mathrm{n}$ \\
\hline $7 \mathrm{c}$ & & $\mathrm{n}$ \\
\hline $7 d$ & & $\mathrm{n}$ \\
\hline $7 e$ & & $>5,400(74 \%)^{b}$ \\
\hline $7 f$ & & 3,700 \\
\hline $7 g$ & & $>5,000(84 \%)$ \\
\hline $7 \mathrm{~h}$ & & $>5,000(62 \%)$ \\
\hline $7 i$ & & 1,800 \\
\hline $7 \mathbf{j}$ & & 700 \\
\hline $7 k$ & & 700 \\
\hline 71 & $\mathbf{N}$ & 360 \\
\hline $7 \mathrm{~m}$ & & 150 \\
\hline $7 n$ & & 340 \\
\hline 70 & $\mathbf{N}$ & 240 \\
\hline
\end{tabular}

a I nactive up to $10 \mathrm{mM}$. ${ }^{\mathrm{b}}$ Remaining enzyme activity at stated inhibitor concentration.

overall greater than 104-fold affinity increase over adenosine. Even though a large number of enzymes use adenosine analogues as cofactors, one could anticipate that highly substituted analogues $\mathbf{9 a}-\mathbf{e}$ would be rather

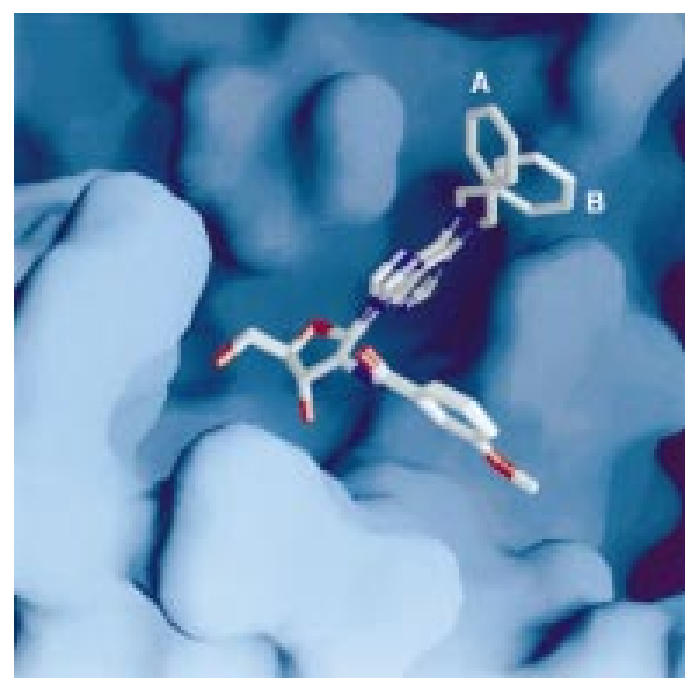

Figure 3. Two possible orientations of the $\mathrm{N}^{6}$-benzyl substituent of 9 a obtained by molecular modeling. Orientation $A$ fits in the narrow cleft, while B sits in the wide cleft.

selective for GAPDH. Compounds such as $\mathbf{9 b}$ are promising antiparasite drug candidates since they may be sufficiently lipophilic to cross parasite membranes in a transporter-independent fashion.

\section{Experimental Section}

General. Anhydrous solvents were obtained as follows: pyridine was distilled after refluxing overnight with $\mathrm{CaH}_{2}$ with a CaSO 4 dry tube; $\mathrm{CH}_{2} \mathrm{Cl}_{2}$ was refluxed overnight with $\mathrm{P}_{2} \mathrm{O}_{5}$ and distilled under $\mathrm{Ar}$; DMF was dried by storing over $4-\AA$ molecular sieves, followed by distillation under reduced pressure. TLC was carried out with precoated silica gel $\mathrm{F}_{254}$ plates (EM Science), and spots were detected with UV light (254 nm). Ninhydrin spray was used for detection of amines. Flash chromatography was carried out with silica gel (0.040-0.063 $\mathrm{mm}$; EM Science). NMR spectra were taken on Bruker AF300 and Bruker WM-500 spectrometers of solutions of $\sim 2-5$ $\mathrm{mg}$ of compound in $0.4 \mathrm{~mL}$ of $\mathrm{CDCl}_{3}$ unless otherwise mentioned. Electrospray ionization (ESI) mass spectra were obtained on a Kratos Profile HV4 mass spectrometer. All target compounds were shown to be pure by reverse-phase $\mathrm{HPLC}$ on $\mathrm{C}_{4}$ and $\mathrm{C}_{18}$ Vydac columns with $\mathrm{MeOH} / \mathrm{H}_{2} \mathrm{O}$ elution gradient.

Inhibition Studies. (1) Enzymes, Substrates, Cofactors. Recombinant L. mexicana, T. cruzi, and T. brucei glycosomal GAPDHs were obtained as a gift from Drs. H. Kim and P. A. M. Michels. ${ }^{33,36} \mathrm{NAD}^{+}$and glyceraldehyde-3phosphate diethyl acetal were purchased from Sigma. Fresh glyceraldehyde-3-phosphate was prepared from its diethyl acetal according to the instructions provided by the manufacturer.

(2) GAPDH Inhibition Assays. The compounds tested were dissolved in DMSO- $d_{6}$, and concentrations were determined by integration of NMR peaks with methylene chloride and/or chloroform as internal standards. NMR spectra were collected with a pulse recycle delay of $8 \mathrm{~s}$. The activity of GAPDH was measured in the direction of NADH formation by monitoring absorption at $340 \mathrm{~nm}$ at $21^{\circ} \mathrm{C}$. The $0.5-\mathrm{mL}$ reaction mixture contained $0.1 \mathrm{M}$ triethanolamine- $\mathrm{HCl}$ buffer, $\mathrm{pH}$ 7.6, $1 \mathrm{mM}$ dithiothreitol, $1 \mathrm{mM} \mathrm{NaN}, 5 \mathrm{mM} \mathrm{MgSO}_{4}, 1 \mathrm{mM}$ EDTA, $10 \mathrm{mM} \mathrm{K}_{2} \mathrm{HPO}_{4}, 0.8 \mathrm{mM}$ glyceraldehyde-3-phosphate, and $0.19 \mathrm{mM} \mathrm{NAD}^{+}$. The concentration of DMSO in the reaction cuvette was kept at $5 \%$. The reaction was started by addition of enzyme. Control reactions were run in the absence of inhibitors but with 5\% DMSO. Remaining activity was calculated as percent of control using the initial velocities measured from 0 to $1 \mathrm{~min}$. Inhibitor concentration in the reaction cuvette was varied, with at least five different 
Table 4. Selective Parasite GAPDH Inhibition by $2^{\prime}, N^{6}$-Disubstituted Adenosine Analogues (IC $\left.50, \mu \mathrm{M}\right)$

\begin{tabular}{clclll}
\hline compd & \multicolumn{1}{c}{ N6-R $^{6}$} & L. mexicana & T. cruzi & T. brucei & human \\
\hline 9a & benzyl & 16 & 159 & 220 & $>530(100 \%)^{b}$ \\
9b & 2-Me-benzyl & 4 & 30 & 30 & $>270(100 \%)^{b}$ \\
$9 \mathbf{9 c}$ & 2-MeO-benzyl & 25 & ND & ND & ND \\
9d & 2,5-diMe-benzyl & 25 & ND & ND & ND \\
9e & 2,3-diMe-benzyl & 5.5 & ND & ND & ND \\
\hline
\end{tabular}

a All parasite GAPDHs are the glycosomal isoform, and the human enzyme is from erythrocytes. ${ }^{\circ}$ I nsoluble above stated concentration. ${ }^{c} \mathrm{ND}$, not determined.

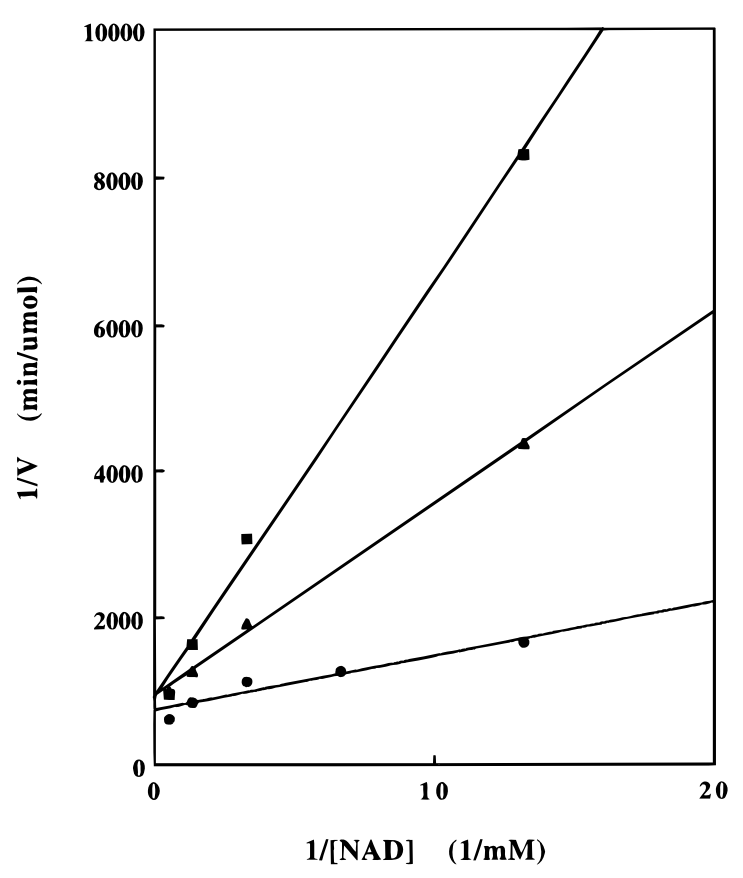

Figure 4. Competitive inhibition of L. mexicana GAPDH with $16 \mu \mathrm{M}$ (triangles) and $32 \mu \mathrm{M}$ (squares) $9 \mathrm{a}$ versus the control (circles).

concentrations used to determine $I C_{50}$ values. Statistical error limits on the $\mathrm{IC}_{50}$ values have been calculated and amount to $10 \%$.

Molecular Modeling. Prior to synthesis, qualitative docking experiments were carried out with the program BIOGRAF 37 in conjunction with the Dreiding force field. ${ }^{38}$ The adenosine moiety was fixed in the position observed in the crystal structure of $\mathrm{T}$. brucei $\cdot \mathrm{NAD}^{+23}$ for the adenosyl portion of $\mathrm{NAD}^{+}$. Substituents were then added to adenosine followed by conjugate gradient energy minimization (with the convergence criterion set to $0.1 \mathrm{kcal} \mathrm{mol}^{-1} \AA^{-1}$ ) in the presence of all enzyme residues within $12 \AA$ of the modeled inhibitor. In all simulations the protein environment was kept rigid except where stated otherwise. Also, a water molecule hydrogen bonding to $\mathrm{N}^{1}$ of adenosine, the main-chain $\mathrm{N}$ of Glu 90 , and the ND2 of Asn 7 was included. The presence of this water molecule can be inferred by analogy with the crystal structure of Bacillus stearothermophilus GAPDH; 39 it is not visible in the T. brucei crystal structure due to the $3.2-\AA$ resolution limit. Because energy calculations were performed in vacuo, the electrostatic potential energy function was turned off. The most important effect of electrostatics, namely, the formation of hydrogen bonds, was taken care of by explicit geometrical hydrogen bond potentials of the Lennard-J ones 12-10 type with angular dependence. This approach avoids the difficulties of calculating and cal ibrating charges for each new ligand and of treating dielectric effects in detail. ${ }^{40}$

For docking compounds $\mathbf{5 b}-\mathbf{f}$ the side-chain conformation of residue Met 38 was allowed to vary in order to alleviate short contacts between the CG atom and the aromatic ring of the 2'-ribosyl substituents. F or docking compounds $\mathbf{9 a}-\mathbf{e}$ the side-chain conformations of residues $M$ et 38 , Leu 122, and Phe 113 were allowed to change to avoid short contacts. The latter two residues are the ones in contact with the $\mathrm{N}^{6}$-purine substituents.

To check conformational preferences of several of our substituents, searches were carried out using the Cambridge Crystallographic Database, ${ }^{41}$ followed by statistical analysis with the accompanying VISTA software. ${ }^{42}$

To examine the conformational energy difference between proximal and distal orientations of methyl with respect to the imidazol e of $\mathrm{N}^{6}$-methyladenine, their energies were calculated with the AM1 Hamiltoninan using the AMSOL 5.0 program. ${ }^{43}$ Full geometry optimization was carried out.

Buried hydrophobic surface calculations were performed with the program NACCESS. ${ }^{44}$

Syntheses. 2'-Amino-2'-deoxy-3',5'-0-(1,1,3,3-tetraisopropylsiloxane-1,3-diyl)adenosine (3) and $\mathrm{N}^{6}$-(3-methyl-2-butenyl)adenosine were synthesized as described. ${ }^{30,45}$

Protection of Hydroxy Acids. Hydroxybenzoic acids were protected via acetylation as described ${ }^{27}$ in $80-95 \%$ yields, and the structures were verified by ${ }^{1} \mathrm{H}$ NMR.

$\mathbf{2}-\mathbf{N}$-Acylation. Each of the acetoxybenzoic acids (150 mg) was suspended in $20 \mathrm{~mL}$ of dry $\mathrm{CH}_{2} \mathrm{Cl}_{2}$, and $100 \mathrm{mg}$ of $\mathrm{PCl}_{5}$ was added with stirring under $\mathrm{Ar}$. The solution was stirred at room temperature for $5 \mathrm{~h}$, then dried in vacuo overnight. To a solution of $30 \mathrm{mg}$ of 3 in $10 \mathrm{~mL}$ of $\mathrm{CH}_{2} \mathrm{Cl}_{2} / 1 \mathrm{~mL}$ of pyridine, was added 3 equiv of acyl chloride, and the mixture was refluxed for $3 \mathrm{~h}$ under Ar. Reaction progress was monitored by TLC ( $10 \% \mathrm{MeOH} / \mathrm{EtOAc:} \mathrm{R}_{\mathrm{f}}=1$ for acyl chloride, 0.5 for product, and 0.05 for 3 ). The solvent was evaporated; the solid was dried in vacuo and redissolved in EtOAc. The solution was extracted twice with saturated $\mathrm{NaHCO}_{3}$, then dried, and chromatographed on silica. Nonpolar impurities were removed with EtOAc, and the product was eluted with $10 \% \mathrm{MeOH} / \mathrm{AcO}$ Et. $\mathrm{R}_{\mathrm{f}}$ values for the derivatives are $\sim 0.4$ using $100 \%$ EtOAc as solvent.

2'-Deoxy-2' -(3-methoxybenzamido)-3',5'-0-(1,1,3,3-tetraisopropyldisiloxane-1,3-diyl)adenosine (4a). The described procedure with $10 \mathrm{mg}(19.7 \mu \mathrm{mol})$ of 3 yielded $9.8 \mathrm{mg}$ (77\%) of the title compound: ${ }^{1} \mathrm{H}$ NMR $\delta 1-1.4(\mathrm{~m}, 28,4 \mathrm{iPr})$,

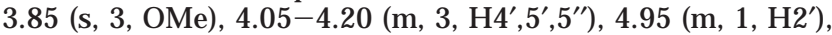
$5.55\left(\mathrm{~m}, 1, \mathrm{H} 3^{\prime}\right), 6.16\left(\mathrm{br} \mathrm{s}, 2, \mathrm{NH}_{2}\right), 6.27\left(\mathrm{~d}, 1, \mathrm{H} \mathrm{l}^{\prime}\right), 7.08(\mathrm{~m}$, 1, H4), 7.26-7.40 (m, 3, H6", 5", 2"'), 8.07 (s, 1, H2'), 8.26 (s, $1, \mathrm{H} 8$ ); identical by NMR and TLC to the reported compound. ${ }^{21}$

2'-Deoxy-2'-(3-methoxy-4-acetoxybenzamido)-3',5'-0(1,1,3,3-tetraisopropyldisiloxane-1,3-diyl)adenosine (4b). The described procedure with $8 \mathrm{mg}(15.7 \mu \mathrm{mol})$ of $\mathbf{3}$ yielded $11.4 \mathrm{mg}(85 \%)$ of title compound: ${ }^{1} \mathrm{H}$ NMR $\delta 0.9-1.3(\mathrm{~m}, 28$, $4 \mathrm{iPr}$ ), 2.33 (s, 3, acetate), 3.85 (s, 3, OMe), 4.05-4.15 (m, 3, $\left.\mathrm{H} 4^{\prime}, 5^{\prime}, 5^{\prime \prime}\right), 4.86$ ( $\left.\mathrm{m}, 1, \mathrm{H} 2^{\prime}\right), 5.57$ (br s, 3, $\left.\mathrm{NH}_{2}, \mathrm{H}^{\prime}\right), 6.09$ (d, 1, $\left.H 1^{\prime}\right), 7.11$ (d, 1, H5"), 7.28 (dd, 1, H6") $7.46\left(d, 1, H 2^{\prime \prime}\right), 8.01$ (s, 1, H2), 8.26 (s, 1, H8).

2'-Deoxy-2'-(3-methoxy-2-acetoxybenzamido)-3',5'-0(1,1,3,3-tetraisopropyldisiloxane-1,3-diyl)adenosine (4c). The described procedure with $13.8 \mathrm{mg}(27.2 \mu \mathrm{mol})$ of $\mathbf{3}$ yielded $6.6 \mathrm{mg}$ (49\%) product: ${ }^{1} \mathrm{H}$ NMR $\delta$ 0.9-1.4 ( $\left.\mathrm{m}, 28,4 \mathrm{iPr}\right), 2.33$ (s, 3, acetate), $3.82(\mathrm{~s}, 3, \mathrm{OMe}), 4.0-4.12\left(\mathrm{~m}, 3, \mathrm{H} 4^{\prime}, 5^{\prime}, 5^{\prime \prime}\right), 4.86$ (m, 1, H2'), 5.50 (m, 1, H3'), 6.00 (br s, 3, $\left.\mathrm{NH}_{2}, \mathrm{H}^{\prime}\right)$ ), 7.05-7.4 (m, 3, H4", 5", 6"), 7.96 (s, 1, H2), 8.2 (s, 1, H8).

2'-Deoxy-2'-(3-acetoxybenzamido)-3',5'-0-(1,1,3,3-tetraisopropyldisiloxane-1,3-diyl)adenosine (4d). The de scribed procedure with $10 \mathrm{mg}(19.7 \mu \mathrm{mol})$ of 3 yielded $11 \mathrm{mg}$ (85\%) of title compound: ${ }^{1} \mathrm{H}$ NMR $\delta 0.85-1.3(\mathrm{~m}, 28,4 \mathrm{iPr})$,

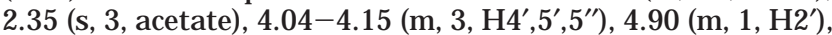


5.55 (t, 1, H3') $6.12\left(\mathrm{~d}, 1, \mathrm{HI}^{\prime}\right), 6.40\left(\mathrm{br} \mathrm{s}, 2, \mathrm{NH}_{2}\right), 7.4-7.7(\mathrm{~m}$, 4, H2", 4", 5", 6"), 8.05 (s, 1, H2), 8.27 (s, 1, H8).

2'-Deoxy-2'-(3,4,5-triacetoxybenzamido)-3',5'-0-(1,1,3,3tetraisopropyldisiloxane-1,3-diyl)adenosine (4e). The described procedure with $23 \mathrm{mg}(45.3 \mu \mathrm{mol})$ of 3 yielded 15 mg (45\%) of title compound: ${ }^{1} \mathrm{H}$ NMR $\delta 0.8-1.3$ (m, 28, $4 \mathrm{iPr}$ ), 2.25-2.31 ( $\mathrm{m}, 9$, acetates), 4.0-4.1 ( $\left.\mathrm{m}, 3, \mathrm{H} 4^{\prime}, 5^{\prime}, 5^{\prime \prime}\right), 4.84$ (m,

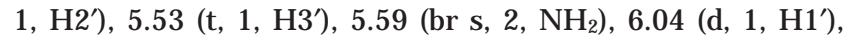
7.52(s, 2, H2", 6") 7.96 (s, 1, H2), 8.24 (s, 1, H8).

''-Deoxy-2'-(3,5-diacetoxybenzamido)-3',5'-0-(1,1,3,3tetraisopropyldisiloxane-1,3-diyl)adenosine (4f). The described procedure with $40 \mathrm{mg}(78.7 \mu \mathrm{mol})$ of 3 yielded $33 \mathrm{mg}$ (60\%) of title compound: ${ }^{1} \mathrm{H}$ NMR $\delta 0.90-1.3(\mathrm{~m}, 28,4 \mathrm{iPr})$, 2.28 (s, 6, acetates), 4.01-4.13 (m, 3, H4',5',5'), 4.85 (m, 1,

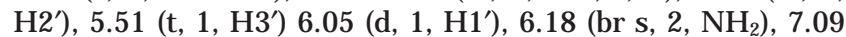
(t, 1, H4"), 7.37 and 7.39 (s, 1 and 1, H2", 6"), 7.99 (s, 1, H2), 8.21 (s, 1, H8).

2'-Deoxy-2'-(3-methoxy-4-hydroxybenzamido)adenosine (5b). Compound $\mathbf{4 b}$ ( $8.8 \mathrm{mg}, 13.4 \mu \mathrm{mol})$ was dissolved in $8 \mathrm{~mL}$ of $10 \% \mathrm{NH}_{3} / \mathrm{MeOH}$ and stirred for $15 \mathrm{~min}$. The solution was dried and subjected to the $\mathrm{NH}_{4} \mathrm{~F}$ deprotection as described, ${ }^{21}$ yielding 5.4 mg of $\mathbf{5 b}(97 \%)$ : ${ }^{1} \mathrm{H}$ NMR (DMSO-d 6 ) $\delta$ 3.58-3.72 (m, 2, H5 $\left.5^{\prime}, 5^{\prime \prime}\right), 3.76(\mathrm{~s}, 3, \mathrm{OMe}), 4.09\left(\mathrm{~m}, 1, \mathrm{H} 4^{\prime}\right)$, $4.29\left(\mathrm{~m}, 1, \mathrm{H} 3^{\prime}\right), 5.29\left(\mathrm{~m}, 1, \mathrm{H} 2^{\prime}\right), 5.61\left(\mathrm{~m}, 1,5^{\prime}-\mathrm{OH}\right), 5.76$ (d, 1, 3'-OH ), 6.17 (d, 1, H $\left.1^{\prime}\right), 6.76$ (d, 1, H5'), 7.28-7.35 (m, 2, H2', $\left.6^{\prime \prime}\right), 8.23$ (br s, 2, NH${ }_{2}$ ), 8.09 (d, 1, NH), 8.11 (s, 1, H2), 8.23 (s, 1, H8).

2'-Deoxy-2'-(3-methoxy-2-hydroxybenzamido)adenosine (5c). The procedure for the synthesis of $\mathbf{5 b}$ was followed for $8.8 \mathrm{mg}$ of $\mathbf{4 c}(13.4 \mu \mathrm{mol})$ and yielded $2.2 \mathrm{mg}(40 \%)$ of $5 \mathrm{c}$ : ${ }^{1} \mathrm{H}$ NMR (DMSO- $\left.\mathrm{d}_{6}\right) \delta 3.6-3.7\left(\mathrm{~m}, 2, \mathrm{H}^{\prime}, 5^{\prime \prime}\right), 3.80$ (s, 3, OMe), $4.10\left(\mathrm{~m}, 1, \mathrm{H} 4^{\prime}\right), 4.35$ ( $\left.\mathrm{m}, 1, \mathrm{H} 3^{\prime}\right), 5.32$ (m, 1, H2'), 5.55-5.75 ( $\left.m, 2,3^{\prime}, 5^{\prime}-\mathrm{OH}\right), 6.12\left(\mathrm{~d}, 1, \mathrm{H} 1^{\prime}\right), 6.7-7.4\left(3 \mathrm{~m}, 3, \mathrm{H} 4^{\prime \prime}, 5^{\prime \prime}, 6^{\prime \prime}\right)$, 7.30 (br s, 2, NH $\mathrm{N}_{2}$ ), 8.10 (s, 1, H2), 8.30 (s, 1, H8), 8.92 (d, 1, $\mathrm{NH})$.

2'-Deoxy-2'-(3-hydroxybenzamido)adenosine (5d). The procedure for the synthesis of $\mathbf{5 b}$ was followed for $11 \mathrm{mg}$ of 4d $(16.8 \mu \mathrm{mol})$ and yielded $4.5 \mathrm{mg}(70 \%)$ of $5 \mathbf{d}$ : ${ }^{1} \mathrm{H}$ NMR (DMSO- $\mathrm{d}_{6}$ ) $\delta 3.58-3.75$ (m, 2, $\left.\mathrm{H}^{\prime} 5^{\prime} \mathrm{5}^{\prime \prime}\right), 4.07$ (br s, 1, H4'), 4.30 (t, 1, H3'), 5.25 (dd, 1, H2'), 5.63 (br s, 1, 5'-OH), 5.71 (d, 1, 3'-OH), 6.17 (d, 1, H $\left.1^{\prime}\right), 6.87$ (m, 1, H4'), 7.15-7.22 (m, 3, H2', $\left.5^{\prime \prime}, 6^{\prime \prime}\right), 7.35$ (br s, 2, $\mathrm{NH}_{2}$ ), 8.10 (s, 1, H2), 8.16 (d, 1, NH), 8.23 (s, 1, H8).

2-Deoxy-2'-(3,4,5-trihydroxybenzamido)adenosine (5e). The procedure for the synthesis of $\mathbf{5 b}$ was followed for $6 \mathrm{mg}$ of $\mathbf{4 e}(9.5 \mu \mathrm{mol})$ and yielded $3.8 \mathrm{mg}(96 \%)$ of $5 \mathbf{e}:{ }^{1} \mathrm{H}$ NMR $\left(\mathrm{MeOH}-\mathrm{d}_{4}\right) \delta 3.75-3.92\left(\mathrm{~m}, 2, \mathrm{H}^{\prime}, 5^{\prime \prime}\right), 4.23$ (br s, 1, H4'), 4.47

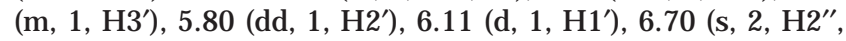
$\left.6^{\prime \prime}\right), 8.17(\mathrm{~s}, 1, \mathrm{H} 2), 8.27$ (s, 1, H8).

2'-Deoxy-2'-(3,5-dihydroxybenzamido)adenosine (5f). The procedure for the synthesis of $\mathbf{5 b}$ was followed for $5 \mathrm{mg}$ of $\mathbf{4 f}(7.2 \mu \mathrm{mol})$ and yielded $2.5 \mathrm{mg}(86 \%)$ of $5 \mathrm{f}$ : ${ }^{1} \mathrm{H}$ NMR (DMSO-d $\left.\mathrm{d}_{6}\right)$ 3.60-3.75 (m, 2, H5', $\left.5^{\prime \prime}\right), 4.08$ (br s, 1, H4'), 4.30 (t, 1, H3'), 5.21 (dd, 1, H2'), 5.63 (br s, 1, 5'-OH), 5.69 (d, 1,

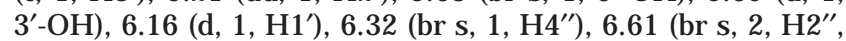
$\left.6^{\prime \prime}\right), 7.33$ (br s, 2, $\mathrm{NH}_{2}$ ), 8.00 (d, 1, NH), 8.13 (s, 1, H2), 8.23 (s, 1, H8).

$\mathbf{N}^{6}$-Acylation. $\mathbf{N}^{6}$-I sobutyryl-2'-deoxy-2'-(3-methoxybenzamido)adenosine (6a). Compound 4 a (9 mg, $14 \mu \mathrm{mol}$ ) was dissolved in $10 \mathrm{~mL}$ of $50 \% \mathrm{CH}_{2} \mathrm{Cl}_{2} / 50 \%$ pyridine, and 30 $\mu \mathrm{L}(0.29 \mathrm{mmol})$ of isobutyryl chloride was added. The mixture was kept at room temperature for $14 \mathrm{~h}$, and solvent was removed in vacuo. The resulting oil was pure by $T L C\left(R_{f} 0.5\right.$ in EtOAc) and was subjected to $\mathrm{NH}_{4} \mathrm{~F}$ deprotection procedure in $\mathrm{MeOH}$ at $45{ }^{\circ} \mathrm{C}$ overnight. The product was chromatographed on silica (10-15\% MeOH/EtOAc): yield $4.5 \mathrm{mg}(45 \%)$; ${ }^{1} \mathrm{H}$ NMR $\left(\mathrm{MeOH}-\mathrm{d}_{4}\right) \delta 1.1-1.2(\mathrm{~d}, 6,2 \mathrm{Me}), 2.9(\mathrm{~m}, 1, \mathrm{CH})$,

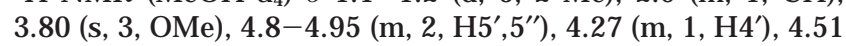
(dd, 1, H3'), 5.35 (dd, 1, H2'), 6.30 (d, 1, H 1'), 7.0-7.5 (m, 4, aromatic protons), 8.56-8.62 (s, 1, H8 and s, 1, H2).
$\mathbf{N}^{6}$-Coupling. All $\mathrm{N}^{6}$-alkyladenosines were synthesized from 6-chloropurine riboside and the corresponding amines under the conditions described by Fleysher in $90-100 \%$ yield. 28,29

$\mathbf{N}^{6}$-I sopropyladenosine (7a): ${ }^{1} \mathrm{H}$ NMR $\left(\mathrm{MeOH}-\mathrm{d}_{4}\right) \delta 1.27-$ $1.32\left(\mathrm{~d}\right.$ of $\left.\mathrm{d}, 6,2 \mathrm{CH}_{3}\right), 3.40(\mathrm{~m}, 1, \mathrm{CH}), 3.68-3.90\left(\mathrm{~m}, 2, \mathrm{H}^{\prime}\right.$, $\left.5^{\prime \prime}\right), 4.18\left(\mathrm{~m}, 1, \mathrm{H} 4^{\prime}\right), 4.30$ (dd, 1, H3'), 4.71 (dd, 1, H2'), 5.91 (d, 1, H I'), 8.18-8.24 (2 s, 2, H8, 2); ESI-MS (methanol) 310.2 $(\mathrm{M}+\mathrm{H})^{+}$

$\mathbf{N}^{6}$-tert-Butyladenosine (7b): ${ }^{1} \mathrm{H}$ NMR $\left(\mathrm{MeOH}-\mathrm{d}_{4}\right) \delta 1.38$ (s, 6, $2 \mathrm{CH}_{3}$ ), 1.62 (s, 3, $\mathrm{CH}_{3}$ ), 3.70-3.95 (m, 2, H5',5"), 4.20 $\left(\mathrm{m}, 1, \mathrm{H} 4^{\prime}\right), 4.32\left(\mathrm{~m}, 1, \mathrm{H} 3^{\prime}\right), 4.77\left(\mathrm{dd}, 1, \mathrm{H} 2^{\prime}\right), 5.94\left(\mathrm{~d}, 1, \mathrm{H} 1^{\prime}\right)$, 8.20-8.24 (s, 2, H8, 2); ESI-MS (methanol) $324.2(\mathrm{M}+\mathrm{H})^{+}$.

$\mathbf{N}^{6}$-Amyladenosine (7c): ${ }^{1} \mathrm{H} N \mathrm{NM}\left(\mathrm{MeOH}-\mathrm{d}_{4}\right) \delta 0.9(\mathrm{~m}, 3$, $\left.\mathrm{CH}_{3}\right), 1.3\left(\mathrm{~m}, 4, \gamma, \delta \mathrm{CH}_{2}\right), 1.65\left(\mathrm{~m}, 2, \beta-\mathrm{CH}_{2}\right), 3.57\left(\mathrm{~m}, 2, \alpha-\mathrm{CH}_{2}\right)$, 3.65-3.9 (m, 2, H5', 5') $4.15\left(\mathrm{~m}, 1, \mathrm{H} 4^{\prime}\right), 4.28\left(\mathrm{dd}, 1, \mathrm{H}^{\prime}\right)$, 4.75 (dd, 1, H2'), 5.90 (d, 1, H 1'), 8.1-8.2 (2 s, 2, H8, 2); ESIMS (methanol) $338.2(\mathrm{M}+\mathrm{H})^{+}$.

N6-(2-Amyl)adenosine (7d): ${ }^{1} \mathrm{H}$ NMR $\left(\mathrm{MeOH}-\mathrm{d}_{4}\right) \delta 0.97$ (dd, 3, $\left.\mathrm{CH}_{3}\right), 1.27\left(\mathrm{dd}, 3, \mathrm{CH}_{3}\right), 1.43\left(\mathrm{~m}, 2, \mathrm{CH}_{2}\right), 1.59(\mathrm{~m}, 2$, $\mathrm{CH}_{2}$ ), $3.29(\mathrm{~m}, 1, \mathrm{CH}), 3.70-3.94\left(\mathrm{~m}, 2, \mathrm{H}^{\prime}, 5^{\prime \prime}\right), 4.18$ (dd, 1,

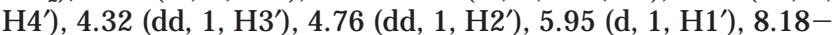
$8.23(2 \mathrm{~s}, 2, \mathrm{H} 8,2)$; ESI-MS (methanol) $338.2(\mathrm{M}+\mathrm{H})^{+}$.

$\mathbf{N}^{6}$-(2-Methylbutyl)adenosine (7e): ${ }^{1} \mathrm{H}$ NMR (MeOH-d $\left.\mathrm{d}_{4}\right)$ $\delta$ 0.92-1.07 (m, 6, 2 $\left.\mathrm{CH}_{3}\right), 1.28\left(\mathrm{~m}, 1, \gamma-\mathrm{CH}_{2}\right), 1.51(\mathrm{~m}, 1$, $\left.\gamma-\mathrm{CH}_{2}\right), 1.78(\mathrm{~m}, 1, \mathrm{CH}), 2.72\left(\mathrm{dd}, 1, \alpha-\mathrm{CH}_{2}\right), 2.90\left(\mathrm{dd}, 1, \alpha-\mathrm{CH}_{2}\right)$, 3.70-3.93 (m, 2, H5', 5'), 4.20 (dd, 1, H4'), 4.34 (dd, 1, H3'), 4.76 (dd, 1, H2'), 5.97 (d, 1, H ' ') , 8.20-8.26 (2 s, 2, H8, 2); ESI-MS (methanol) $338.2(\mathrm{M}+\mathrm{H})^{+}$.

$\mathbf{N}^{6}$-Isoamyladenosine (7f): ${ }^{1} \mathrm{H}$ NMR $\left(\mathrm{MeOH}-\mathrm{d}_{4}\right) \delta 1.0(\mathrm{~d}$, 6, $\left.2 \mathrm{CH}_{3}\right), 1.62\left(\mathrm{~m}, 2, \beta-\mathrm{CH}_{2}\right), 1.72(\mathrm{~m}, 1, \mathrm{CH}), 2.88(\mathrm{~m}, 2$, $\alpha-\mathrm{CH}_{2}$ ), 3.7-3.95 (m, 2, H5', 5'), $4.20\left(\mathrm{~m}, 1, \mathrm{H} 4^{\prime}\right), 4.32$ (dd, 1, $\mathrm{H}^{\prime}$ ) , 4.74 (dd, 1, H2') $5.94\left(\mathrm{~d}, 1, \mathrm{H}^{\prime}\right.$ ), $8.20-8.25$ (2 s, 2, H8, 2); ESI-MS (methanol) $338.3(\mathrm{M}+\mathrm{H})^{+}$.

$\mathbf{N}^{6}$-Cyclopentyladenosine (7h): ${ }^{1} \mathrm{H}$ NMR $\left(\mathrm{MeOH}-\mathrm{d}_{4}\right) \delta$ $1.70\left(\mathrm{~m}, 4,2 \beta-\mathrm{CH}_{2}\right), 2.10\left(\mathrm{~m}, 4,2 \alpha-\mathrm{CH}_{2}\right), 3.58(\mathrm{~m}, 1, \mathrm{CH})$, 3.70-3.93 (m, 2, H5', 5') 4.19 (dd, 1, H4 $\left.4^{\prime}\right), 4.33$ (dd, 1, H3'), 4.75 (dd, 1, H2'), 5.94 (d, 1, H1'), 8.20-8.25 (2 s, 2, H8, 2); ESI-MS (methanol) $336.2(\mathrm{M}+\mathrm{H})^{+}$

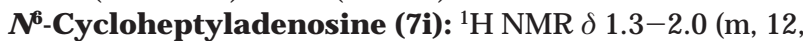
aliphatic protons), $3.0(\mathrm{~m}, 1, \alpha-\mathrm{CH}), 3.7-3.9\left(\mathrm{~m}, 2, \mathrm{H} 5^{\prime}, 5^{\prime \prime}\right)$, 4.25 (m, 1, H4'), 4.35 (dd, 1, H3'), 4.90 (dd, 1, H2'), 5.77 (d, 1, H1'), 5.94 (br s, 1, NH), 7.80 (s, 1, H2), 8.20 (s, 1, H8); ESI-MS (methanol) $364.3(\mathrm{M}+\mathrm{H})^{+}$

$\mathbf{N}^{6}$-(2-Methylbenzyl)adenosine (7j): ${ }^{1} \mathrm{H}$ NMR (MeOH- $\left.\mathrm{d}_{4}\right)$ $\delta 2.4\left(\mathrm{~s}, 3, \mathrm{CH}_{3}\right), 3.7-3.9\left(\mathrm{~m}, 2, \mathrm{H}^{\prime}, 5^{\prime \prime}\right), 4.15\left(\mathrm{~m}, 1, \mathrm{H} 4^{\prime}\right), 4.31$ (dd, 1, H3'), 4.77 (dd, 1, H2'), 5.94 (d, 1, H1'), 7.1-7.4 (m, 4, aromatic protons), 8.22 ( $2 \mathrm{~s}, 2, \mathrm{H} 8,2)$; ESI-MS (methanol) $372.3(\mathrm{M}+\mathrm{H})^{+}$.

$\mathrm{N}^{6}$-(3-Methylbenzyl)adenosine (7k): ${ }^{1} \mathrm{H} \mathrm{NMR}\left(\mathrm{MeOH}-\mathrm{d}_{4}\right)$ $\delta 2.32\left(\mathrm{~s}, 3, \mathrm{CH}_{3}\right), 3.7-3.9\left(\mathrm{~m}, 2, \mathrm{H}^{\prime}, 5^{\prime \prime}\right), 3.87\left(\mathrm{~s}, 2, \mathrm{CH}_{2}\right), 4.18$ ( $\left.\mathrm{m}, 1, \mathrm{H} 4^{\prime}\right), 4.31$ (dd, 1, H3'), 4.75 (dd, 1, H2'), 5.93 (d, 1, H 1'), 6.95-7.2 (m, 4, aromatic protons), 8.2 (2 s, 2, H8, 2); ESI-MS (methanol) $372.3(\mathrm{M}+\mathrm{H})^{+}$

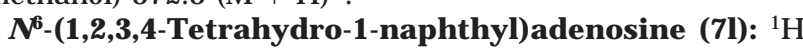
NMR $\delta$ 1.8-2.4 (m, 6, H2", H3", $\left.\left.\mathrm{H}^{\prime \prime}\right)^{\prime \prime}\right), 3.65-3.95$ (m, 2, H5', $\left.5^{\prime \prime}\right), 4.14\left(\mathrm{~m}, 1, \mathrm{H} 4^{\prime}\right), 4.29\left(\mathrm{~m}, 1, \mathrm{H} 3^{\prime}\right), 4.4\left(\mathrm{~m}, 1, \mathrm{H} 1^{\prime \prime}\right), 4.98(\mathrm{~m}$, 1, H ' $), 5.75$ (d, 1, H ' $\left.{ }^{\prime}\right), 6.20$ (br s, 1, NH), 7.0-7.2 (m, 4, H5", $\left.6^{\prime \prime}, 7^{\prime \prime}, 8^{\prime \prime}\right), 7.70(\mathrm{~s}, 1, \mathrm{H} 2), 8.28$ (s, 1, H8); ESI-MS (methanol) $398.2(\mathrm{M}+\mathrm{H})^{+}$.

N6-(1-Naphthalenemethyl)adenosine (7m): ${ }^{1} \mathrm{H}$ NMR $\delta$ 3.7-3.95 (m, 2, H5', 5'), 4.20 (m, 1, H4'), 4.33 (m, 1, H3'), 4.40 (s, 2, $\mathrm{CH}_{2}$ ), $4.78\left(\mathrm{~m}, 1, \mathrm{H} 2^{\prime}\right), 5.93$ (d, 1, H $\left.1^{\prime}\right), 7.4-8.1$ (m, 7, aromatic protons), 8.19-8.23 (2 s, 2, H8, 2); ESI-MS (methanol) $408.1(\mathrm{M}+\mathrm{H})^{+}$.

N6-[2-(2-(Hydroxymethyl)phenylthio)benzyl]adenosine (7n): ${ }^{1} \mathrm{H}$ NMR $\delta 3.71-3.91\left(\mathrm{~m}, 2, \mathrm{H}^{\prime}, \mathrm{H}^{\prime \prime}\right), 4.18(\mathrm{~m}, 1$, $\mathrm{H}^{\prime}$ ), 4.31 (dd, 1, H3'), 4.70 (s, 2, $\left.\mathrm{CH}_{2} \mathrm{O}\right), 4.73$ (dd, 1, H2'), 4.90 (br s, 2, $\left.\mathrm{CH}_{2} \mathrm{~N}\right), 5.91$ (d, 1, $\left.\mathrm{Hl}^{\prime}\right)$, 7.05-7.50 (m, 8, aromatic protons), 8.15-8.25 (2 s, 2, H8, 2); ESI-MS (methanol) 496.2 $(\mathrm{M}+\mathrm{H})^{+}$.

N $^{6}$-(Diphenylmethyl)adenosine (7o): ${ }^{1} \mathrm{H}$ NMR (MeOH$\left.\mathrm{d}_{4}\right) \delta 3.7-3.9\left(\mathrm{~m}, 2, \mathrm{H} 5^{\prime}, 5^{\prime \prime}\right), 4.17\left(\mathrm{~m}, 1, \mathrm{H} 4^{\prime}\right), 4.29$ (dd, 1, H3'), 4.72 (dd, 1, H2'), 5.34 (s, 1, CH) , 5.92 (d, 1, H $\left.1^{\prime}\right), 7.2-7.35$ (m, 
10, aromatic protons), 8.17 (s, 1, H2), 8.26 (s, 1, H8); ESI-MS $434.0(\mathrm{M}+\mathrm{H})^{+}$.

$\mathbf{N}^{6}$-Alkylation. $\mathbf{N}^{6}$-Benzyl-2'-deoxy-2 -(3-methoxybenzamido)-3',5'-0-(1,1,3,3-tetraisopropyldisiloxane-1,3-diyl)adenosine (8a). Benzyl bromide (0.12 mL, $1 \mathrm{mmol}$ ) was added to a solution of $24 \mathrm{mg}(37.4 \mu \mathrm{mol})$ of $\mathbf{4 a}$ in $5 \mathrm{~mL}$ of DMF, and the mixture was kept at $45^{\circ} \mathrm{C}$ for $14 \mathrm{~h}$ until no starting material could be detected by TLC (EtOAc). DMF was evaporated in vacuo, and the remaining oil was dried by coevaporation with $\mathrm{MeOH}$. It was then dissolved in $25 \%$ i $\mathrm{PrNH}_{2} / 75 \% \mathrm{MeOH}$ and slowly refluxed for $24 \mathrm{~h}$. The solid was dried and chromatographed on silica with 1:1 hexane/ EtOAc $\left(\mathrm{R}_{\mathrm{f}} 0.7\right.$ in EtOAc): yield $14.3 \mathrm{mg}(52 \%)$; ${ }^{1} \mathrm{H}$ NMR $\delta$ 0.85-1.2 (m, 28, $4 \mathrm{iPr}$ ), 3.81 (s, 3, OMe), 3.89-4.15 (m, 2, H5', $\left.5^{\prime \prime}\right), 4.25$ (d, 1, H4'), 4.80 (m, 3, H2', $\mathrm{CH}_{2}$ ), 5.26 (t, 1, H3'), 6.12 (d, 1, H ' $\left.{ }^{\prime}\right), 6.43$ (br s, 1, NH amine), 7.2-7.4 (m, 9, aromatic protons), 8.02 (s, 1, H2), 8.34 (s, 1, H8).

N6-(3-Methyl-2-butenyl)adenosine (7g). 4-Bromo-2methyl-2-butene $(0.05 \mathrm{~mL}, 0.43 \mathrm{mmol})$ was added to a solution of $30 \mathrm{mg}(112 \mu \mathrm{mol})$ of adenosine and $35 \mathrm{mg}$ of $\mathrm{BaCO}_{3}$ in $5 \mathrm{~mL}$ of DMF, and the mixture stirred at room temperature in the dark for 48 h. DMF was evaporated in vacuo, and the rearrangement was performed in a similar manner as for $\mathbf{1 0 a}$ yielding $11.8 \mathrm{mg}$ (31\%) of title compound: ${ }^{1} \mathrm{H}$ NMR $\delta 1.7(\mathrm{br}$ $\left.\mathrm{s}, 6,2 \delta-\mathrm{CH}_{3}\right), 3.65-3.95\left(\mathrm{~m}, 2, \mathrm{H}^{\prime}, 5^{\prime \prime}\right), 4.15\left(\mathrm{~m}, 1, \mathrm{H} 4^{\prime}\right), 4.30$ $\left(\mathrm{m}, 1, \mathrm{H}^{\prime}\right), 4.15$ and $4.40\left(\mathrm{~m}, 2, \alpha-\mathrm{CH}_{2}\right), 5.0\left(\mathrm{~m}, 1, \mathrm{H} 2^{\prime}\right), 5.30$ (t, 1, $\beta$-CH) $5.78\left(\mathrm{~d}, 1, \mathrm{H} 1^{\prime}\right), 6.0(\mathrm{br} \mathrm{s}, 1, \mathrm{NH}), 7.75(\mathrm{~s}, 1, \mathrm{H} 2)$, 8.05 (s, 1, H8); ESI-MS (methanol) $336.3(\mathrm{M}+\mathrm{H})^{+}$

$\mathbf{N}^{6}$-Benzyl-2'-deoxy-2'-(3-methoxybenzamido)adenosine (9a). Deprotection procedure described for $\mathbf{1}^{21}$ starting with $2.1 \mathrm{mg}(4.3 \mu \mathrm{mol})$ of 8 a gave quantitative yield of product, which was purified on silica $\left(R_{f} 0.25\right.$ in EtOAc) and on a $C_{18}$ Sep-Pak cartridge (loaded in $\mathrm{MeOH} / \mathrm{H}_{2} \mathrm{O}$ and eluted with $\mathrm{MeOH}$ ): ${ }^{1} \mathrm{H}$ NMR (DMSO- $\left.\mathrm{d}_{6}\right) \delta 3.58-3.72\left(\mathrm{~m}, 2, \mathrm{H}^{\prime}, 5^{\prime \prime}\right), 3.76$ (s, 3, OMe), $4.08\left(\mathrm{~m}, 1, \mathrm{H} 4^{\prime}\right), 4.32\left(\mathrm{~m}, 1, \mathrm{H} 3^{\prime}\right), 4.68$ (br s, 2, $\left.\mathrm{CH}_{2}\right), 5.30\left(\mathrm{~m}, 1, \mathrm{H}^{\prime}\right), 5.57$ (dd, 1, 5'-OH), 5.72 (d, 1, 3'-OH), $6.21\left(\mathrm{~d}, 1, \mathrm{H}^{\prime}\right), 7.1-7.4(\mathrm{~m}, 9$, aromatic protons), 8.17 (s, 1 , H2), 8.27 (s, 1, H8), 8.33 (d, 1, NH amide); ESI-MS (methanol) $491.2(\mathrm{M}+\mathrm{H})^{+}$

$\mathbf{N}^{6}$-(2-Methylbenzyl)-2'-deoxy-2 -(3-methoxybenzamido)adenosine (9b). The procedures for $\mathbf{8 a}$ and $\mathbf{9 a}$ were applied in sequence using $15.6 \mathrm{mg}(24.3 \mu \mathrm{mol})$ of $\mathbf{4 a}$ and $0.12 \mathrm{~mL}$ (166 $\mathrm{mg}, 0.9 \mathrm{mmol}$ ) of 2-methylbenzyl bromide. The overall yield for the two steps was $0.7 \mathrm{mg}(6 \%)$ : ${ }^{1} \mathrm{H}$ NMR (DMSO-d 6 ) $\delta 2.32$ (s, 3, $\left.\mathrm{CH}_{3}\right), 3.6-3.75\left(\mathrm{~m}, 2, \mathrm{H}^{\prime}, 5^{\prime \prime}\right), 3.79$ (s, 3, OMe), 4.10 (m, $\left.1, \mathrm{H}^{\prime}\right), 4.32$ (m, 1, H3'), 4.65 (br s, 2, $\left.\mathrm{CH}_{2}\right), 5.30$ (m, 1, H2'), 5.59 (dd, 1, 5'-OH), 5.72 (d, 1, 3'-OH), 6.21 (d, 1, H 1'), 7.057.45 (m, 8, aromatic protons), 8.18 (s, 1, H2), 8.29 (s, 1, H8), 8.34 (d, 1, NH amide); ESI-MS (methanol) $505.3(\mathrm{M}+\mathrm{H})^{+}$.

N6-(2-Methoxybenzyl)-2-deoxy-2-(3-methoxybenzamido)adenosine (9c). The overall yield for the two steps was 38\%: ${ }^{1} \mathrm{H}$ NMR $\left(\mathrm{MeOH}-\mathrm{d}_{4}\right) \delta 3.81\left(\mathrm{~m}, 1, \mathrm{H}^{\prime}\right), 3.92\left(\mathrm{~m}, 1, \mathrm{H} 5^{\prime \prime}\right)$, 3.79, $3.86(2 \mathrm{~s}, 6,2 \mathrm{OMe}), 4.28\left(\mathrm{~m}, 1, \mathrm{H}^{\prime}\right), 4.50\left(\mathrm{~m}, 1, \mathrm{H} 3^{\prime}\right)$, 4.77 (br s, 2, $\mathrm{CH}_{2}$ ), 5.38 (m, 1, H2'), 6.19 (d, 1, H 1'), 6.85-7.30 ( $\mathrm{m}, 8$, aromatic protons), $8.22(2 \mathrm{~s}, 2, \mathrm{H} 8,2)$; ESI-MS (methanol) $521.4(\mathrm{M}+\mathrm{H})^{+}$.

N6-(2,5-Dimethylbenzyl)-2'-deoxy-2' -(3-methoxybenzamido)adenosine (9d). The overall yield for the two steps was 25\%: ${ }^{1} \mathrm{H}$ NMR (DMSO-d $) \delta 2.13,2.27\left(2 \mathrm{~s}, 6,2 \mathrm{CH}_{3}\right)$, 3.58-3.75 (m, 2, H5', 5"), 3.76 (s, 3, OMe), 4.09 (m, 1, H4'), $4.32\left(\mathrm{~m}, 1, \mathrm{H}^{\prime}\right), 4.61\left(\mathrm{br} \mathrm{s}, 2, \mathrm{CH}_{2}\right), 5.30\left(\mathrm{~m}, 1, \mathrm{H} 2^{\prime}\right), 5.59$ (dd, 1, 5'-OH), $5.73\left(\mathrm{~d}, 1,3^{\prime}-\mathrm{OH}\right), 6.21\left(\mathrm{~d}, 1, \mathrm{H}^{\prime} \mathrm{1}^{\prime}\right), 6.9-7.45(\mathrm{~m}, \mathrm{7}$, aromatic protons), $8.19(\mathrm{~s}, 1, \mathrm{H} 2), 8.29(\mathrm{~s}, 1, \mathrm{H} 8), 8.36(\mathrm{~d}, 1$, $\mathrm{NH}$ amide); ESI-MS (methanol) $519.3(\mathrm{M}+\mathrm{H})^{+}$.

N $^{6}$-(2,3-Dimethylbenzyl)-2'-deoxy-2' -(3-methoxybenzamido)adenosine (9e). The overall yield for the two steps was 11\%: ${ }^{1 \mathrm{H}} \mathrm{NMR}\left(\mathrm{MeOH}-\mathrm{d}_{4}\right) \delta 2.26,2.29\left(2 \mathrm{~s}, 6,2 \mathrm{CH}_{3}\right), 3.79(\mathrm{~s}$, 3, OMe), 3.8-3.93 (m, 2, H5', 5'), 4.27 ( $\left.\mathrm{m}, 1, \mathrm{H} 4^{\prime}\right), 4.5$ (m, 1, $\left.\mathrm{H}^{\prime}\right), 4.75$ (br s, 2, $\left.\mathrm{CH}_{2}\right), 5.38\left(\mathrm{~m}, 1, \mathrm{H} 2^{\prime}\right), 6.2\left(\mathrm{~d}, 1, \mathrm{H} 1^{\prime}\right), 7.0-$ 7.35 (m, 7, aromatic protons), 8.22-8.27 (2 s, 2, H8,2); ESIMS (methanol) $519.3(\mathrm{M}+\mathrm{H})^{+}$.

Acknowledgment. This work was supported by Grant HL 36235 from the National Institutes of Heal th to M.H.G. A.M.A. is the recipient of a Dow Chemical Fellowship Award. We wish to thank Drs. Paul A. Michels and Hidong Kim for providing a source of enzyme and Murdock Charitable Trust for a major equipment grant to the University of Washington Biomolecular Structure Center.

\section{References}

(1) WHO Consultation Program. Bull. W. H. O. 1982, 60, 821-825.

(2) Clayton, C.; Haeusler, T.; Blattner, J. Protein Trafficking in Kinetoplastid Protozoa. Microbiol. Rev. 1995, 59, 325-344.

(3) Despommier, D. D.; Gwadz, R. W.; Hotez, P. J. Parasitic Diseases; Springer-Verlag: New York, 1995; pp 196-203.

(4) Meshnick, S. R. In Parasitic Diseases; Mansfield, J. M., Ed. Marcel Dekker: New York, 1984; Vol. 2, pp 165-199.

(5) Rew, R. S. Protozoan Infections of Man: African Trypanosomiasis. In Chemotherapy of Parasitic Diseases; Campbell, W. C., Rew, R. S., Eds.; Plenum: New York, 1986; pp 129-138.

(6) Bitonti, A. J .; Byers, T. L.; Bush, T. L.; Casara, P. J .; Bacchi, C. J .; Clarkson, J.; McCann, P. P.; Sjoerdsma, A. Cure of Trypanosoma bruce brucei and Trypanosoma bruce rhodesiense Infections in Mice with an Irreversible Inhibitor of S-Adenosylmethionine Decarboxylase. Antimicrob. Agents Chemother. 1990, 34, 1485-1490.

(7) Bacchi, C. J .; Nathan, H. C.; Yarlett, N.; Goldberg, B.; McCann, P. P.; Sjoerdsma, A.; Saric, M.; Clarkson, A. B., J r. Combination Chemotherapy of Drug-Resistant Trypanosoma brucei rhodesiense Infections in Mice Using DL- $\alpha$-Difluoromethylornithine and Standard Trypanocides. Antimicrob. Agents Chemother. 1994, 34, 563-569.

(8) Gutteridge, W. E. Existing Chemotherapy and its Limitations. Br. Med. Bull. 1985, 41, 162-168.

(9) Metcalf, B. W.; Bey, P.; Danzin, C.; J ung, M. J .; Casara, P.; Vevert, J. P. Catalytic Irreversible Inhibition of Mammalian Ornithine Decarboxylase (4.1.1.17) by Substrate and Product Analogues. J . Am. Chem. Soc. 1978, 100, 2551-2553.

(10) Schechter, P.J .; Barlow, J . R. L.; Sjoerdsma, A. Clinical Aspects of Inhibition of Ornithine Decarboxylase with Emphasis on Therapeutic Trials of Eflornithine (DFMO) in Cancer and Protozoan Disease. In Inhibition of Polyamine Metabolism; McCann, P. P., Pegg, A. E., Sjoerdsma, A., Eds.; Academic: New York, 1987; pp 345-364.

(11) Trop. Drug Res. News 1990, 34, 1.

(12) Bell ofatto, V.; Fairlamb, A.; Henderson, G. B.; Cross, G. A. M. Biochemical changes associated with $\alpha$-difluoromethylornithine uptake and resistance in Trypanosoma brucei. Mol. Biochem. Parasitol. 1987, 25, 227-238.

(13) Opperdoes, F. R. Biochemical Peculiarities of Trypanosomes, African and South American. Br. Med. Bull. 1985, 41, 130-136.

(14) Opperdoes, F. R. Compartmentation of Carbohydrate Metabolism in Trypanosomes. Annu. Rev. Microbiol. 1987, 41, 127151.

(15) Clarkson, A. B., J r.; Brohn, F. H. Trypanosomiasis: An Approach to Chemotherapy by the Inhibition of Carbohydrate Catabolism. Science 1976, 194, 204-206.

(16) Lambeir, A.-M.; Loiseau, A. M.; Kuntz, D. A.; Vellieux, F. M.; Michels, P. A. M.; Opperdoes, F. R. The cytosolic and glycosomal glyceral dehyde-3-phosphate dehydrogenase from Trypanosoma bruce. Kinetic properties and comparison with homologous enzymes. Eur. J. Biochem. 1991, 198, 429-435.

(17) Bakker, B. M.; Michels, P. A. M.; Opperdoes, F. R.; Westerhoff, H. V. Glycolysis in Bloodstream Form Trypanosoma brucei Can Be Understood in Terms of the Kinetics of the Glycolytic Enzymes. J . Biol. Chem. 1997, 272, 3207-3215.

(18) Eisenthal, R.; Cornish-Bowden, A. Prospects for Antiparasitic Drugs. J. Biol. Chem. 1998, 273, 5500-5505.

(19) Bakker, B. M. Control and Regulation of Glycolysis in Trypanosoma brucei. Ph.D. Thesis, Free University of Amsterdam, 1998.

(20) Verlinde, C. L. M. J .; Callens, M.; Van Calenbergh, S.; Van Aerschot, A.: Herdewijn, P.; Hannaert, V.: Michels, P. A. M.: Opperdoes, F. R.; Hol, W. G. J . Selective Inhibition of Trypanosomal Glyceraldehyde-3-Phosphate Dehydrogenase by Protein Structure-Based Design: Toward New Drugs for the Treatment of Sleeping Sickness. J. Med. Chem. 1994, 37, 3605-3613.

(21) Van Calenbergh, S.; Van Den Eeckhout, E.; Herdewijn, P.; De Bruyn, A.; Verlinde, C.; Hol, W.; Callens, M.; Van Aerschot, A.; Rozenski, J. Synthesis and Conformational Analysis of 2'-Deoxy2'-(3-methoxybenzamido)adenosine, a Rational-Designed Inhibitor of Trypanosomal Glyceraldehyde Phosphate Dehydrogenase (GAPDH). Helv. Chim. Acta 1994, 77, 631-644.

(22) Van Calenbergh, S.; Verlinde, C. L. M. J .; Soenens, J .; De Bruyn, A.; Callens, M.; Blaton, N. M.; Peeters, O. M.; Rozenski, J .; Hol W. G. J .; Herdewijn, P. Synthesis and Structure-Activity 
Relationships of Analogues of 2'-Deoxy-2'-(3-methoxybenzamido)adenosine, a Selective I nhibitor of Trypanosomal Glycosomal Glyceraldehyde-3-phosphate Dehydrogenase. J. Med. Chem. 1995, 38, 3838-3849.

(23) Vellieux, F. M. D.; Hajdu, J .; Verlinde, C. L. M. J .; Groendijk, H.; Read, R. J .; Greenhough, T. J .; Campbell, J. W.; Kalk, K. H.; Littlechild, J . A.; Watson, H. C.; Hol, W. G. J . Structure of glycosomal glyceraldehyde-3-phosphate dehydrogenase from Trypanosoma brucei determined from Laue data. Proc. Natl. Acad. Sci. U.S.A. 1993, 90, 2355-2359.

(24) Willson, M.; Lauth, N.; Perie, J .; Callens, M.; Opperdoes, F. R. Inhibition of Glyceraldehyde-3-Phosphate Dehydrogenase by Phosphorylated E poxides and $\alpha$-Enones. Bi ochemistry 1994, 33, 214-220.

(25) Saenger, W. Principles of Nucleic Acid Structure; SpringerVerlag: New York, 1984

(26) Robins, M.J .; Wilson, J. S.; Hansske, F. Nucleic Acid Related Compounds. 42. A General Procedure for the Efficient Deoxygenation of Secondary Alcohols. Regiospecific and Stereosel ective Conversion of Ribonucleosides to 2'-Deoxynucleosides. J . Am. Chem. Soc. 1983, 105, 4059-4065.

(27) White, B. B.; Barabash, E. U.S. Patent 2581 565, 1952; Chem. Abstr. 1952, 46, 5842.

(28) Fleysher, M. H.; Hakala, M. T.; Bloch, A.; Hall, R. H. Synthesis and Biological Activity of Some N6-Alkyladenosines. J . Med. Chem. 1968, 11, 717-720.

(29) Fleysher, M. H. N6-Substituted Adenosines: Synthesis, Biological Activity, and SomeStructure-Activity Relationships. J . Med. Chem. 1972, 15, 187-191.

(30) Robins, M. J.; Trip, E. M. Sugar-Modified N6-(3-Methyl-2butenyl)adenosine Derivatives, N6-Benzyl analogues, and Cytokinin-Related Nucleosides Containing Sulfur or Formycin. Biochemistry 1973, 12, 2179-2187.

(31) Drew, J .; Letellier, M.; M orand, P.; Szabo, A. G. Synthesis from Pregnenol one of Fluorescent Cholesterol Analogue Probes with Conjugated Unsaturation in the Side Chain. J . Org. Chem. 1987, $52,4047-4052$.

(32) Raederstorff, D.; Shu, A. Y. L.; Thompson, J . E.; Djerassi, C. Biosynthetic Studies of Marine Lipids. 11. Synthesis, Biosynthesis, and Absolute Configuration of the Internally Branched Demospongic Acid, 22-Methyl-5,9-Octacosadienoic acid. J . Org. Chem. 1987, 52, 2337-2346.

(33) Kim, H.; Feil, I.; Verlinde, C. L. M. J .; Petra, P. H.; Hol, W. G. J. Crystal Structure of Glycosomal Glyceral dehyde-3-Phosphate Dehydrogenase from Leishmania Mexicana: Implications for Structure-Based Drug Design and a New Position for the Inorganic Phosphate Binding Site. Biochemistry 1995, 34, 14975-14986.
(34) Quideau, S.; Feldman, K. S.; Appel, H. M. Chemistry of GalloylDerived o-Quinones: Reactivity Toward Nucleophiles. J . Org. Chem. 1995, 60, 4982-4983.

(35) Harvey, R. G. Polycyclic Hydrocarbons and Carcinogenesis. ACS Monograph No. 283; American Chemical Society: Washington, DC, 1985.

(36) Hannaert, V.; Opperdoes, F. R.; Michels, P. A. M. Glycosomal Glyceraldehyde-3-Phosphate Dehydrogenase of Trypanosoma bruce and Trypanosoma cruzi: Expression in Escherichia coli, Purification and Characterization of the Enzymes. Protein Expr. Purif. 1995, 6, 244-250.

(37) Molecular Simulations Inc., Biograf 3.10; San Diego, CA

(38) Mayo, S. L.; Olafson, B. D.; Goddard, W. A., III. DREIDING: A Generic Force Field for Molecular Simulations. J . Phys. Chem. 1990, 94, 8897-8909.

(39) Skarzynski, T.; Moody, P. C. E.; Wonacott, A. J . Structure of the holo-glyceraldehyde-3-phosphate dehydrogenase from Bacillus stearothermophilus at 1.8 A resolution. J . Mol. Biol. 1987, 193, 171-187.

(40) Mueller, K.; Amman, H.-J .; Doran, D.; Gerber, P. R.; Gubernator, K.; Schrepfer, G. The Use of Computer Modeling and Structural Databases in Pharmaceutical Research. In Trends in Medicinal Chemistry '88; van der Goot, H., Domany, G., Pallos, L., Timmerman, H., Eds.; Elsevier Science Publishers: Amsterdam, 1989; pp 1-12.

(41) Allen, F. H.; Davies, J . E.; Galloy, J . J .; J ohnson, O.; Kennard, O.; Macrea, C. F.; Mitchell, E. M.; Mitchell, G. F.; Smith, M.J .; Watson, D. G. The Development of Versions 3 and 4 of the Cambridge Crystallographic Database System. J . Chem. Inf. Comput. Sci. 1993, 31, 187-204.

(42) Watson, D. G. The Cambridge Structural Database (CSD): Current Activities and Future Plans. J . Res. Natl. Inst. Stand. Technol. 1996, 101, 227-229.

(43) Liotard, D. A.; Hawkins, G. D.; Lynch, G. C.; Cramer, C. J .; Truhlar, D. G. Improved Methods for Semiempirical Solvation Models. J . Comput. Chem. 1995, 16, 422-440.

(44) Hubbard, S. J .; Thornton, J . M. NACCESS, London.

(45) Robins, M. J .; Hawrelak, S. D.; Hernandez, A. E.; Wnuk, S. F. Nucleic Acid Related Compounds. 71. Efficient General Synthesis of Purine (Amino, Azido, and Triflate)-Sugar Nucleosides. Nucl eosides Nucleotides 1992, 11, 821-834.

J M9802620 